PontIFícIA UNIVERSIDADE CATÓLICA dO RIO DE JANEIRO

\title{
Planejamento Estratégico: lacunas entre elaboração e execução
}

Henrique Pires

Trabalho de Conclusão de Curso

CENTRO de CIÊNCIAS SOCIAIS - CCS

DEPARTAMENTO DE ADMINISTRAÇÃO

Graduação em Administração de Empresas 
Henrique Pires

Planejamento Estratégico: lacunas entre elaboração e execução

Trabalho de Conclusão de Curso

Trabalho de Conclusão de Curso, apresentado ao programa de graduação em Administração da PUC-Rio como requisito parcial para a obtenção do titulo de graduação em Administração.

Orientador: Edmundo Eutrópio

Rio de Janeiro, junho de 2016. 


\section{Resumo}

PIRES, Henrique. Planejamento Estratégico: lacunas entre elaboração e execução. Rio de Janeiro, 2016. 52 páginas p. Trabalho de Conclusão de Curso - Departamento de Administração. Pontifícia Universidade Católica do Rio de Janeiro. Orientador: Edmundo Eutrópio

Planejar é um verbo extremamente utilizado no contexto organizacional. Esta ação busca antecipar determinados acontecimentos futuros e definir os planos de ação. Assim ocorre com a estratégia, através do Planejamento Estratégico. O Planejamento Estratégico direciona uma companhia para seu caminho correto. Porém, a estratégia confeccionada deve ser executada no período planejado, e todos os colaboradores devem estar engajados nesse cumprimento. Uma vez cumprido, já que se planejou de forma antecipada, as chances de sucesso são elevadas. O presente trabalho visa entender a fidelidade no cumprimento da estratégia planejada. Ou seja, definiram-se todos os componentes estratégicos, mas eles são efetivamente cumpridos?

Palavras-chave:

Estratégia; Planejamento Estratégico; Alinhamento Estratégico; Execução.

\section{Abstract}

PIRES, Henrique. Planejamento Estratégico: lacunas entre elaboração e execução. Rio de Janeiro, 2016. 52 páginas p. Trabalho de Conclusão de Curso - Departamento de Administração. Pontifícia Universidade Católica do Rio de Janeiro. Orientador: Edmundo Eutrópio

In the organizational context, to plan is a very used verb. This action aims to anticipate certain future events and define action plans. This occurs with the strategy, through the Strategic Planning. Strategic Planning directs a company to its correct way. However, the strategy made must be performed in a planned period, and all employees must be engaged in this compliance. Once performed, as it was planned in advance, the chances of success are significantly high. This study aims to understand the accuracy in performing the planned strategy. That is, all strategic components were defined, but are they actually performed?

Key-words:

Strategy; Strategic Planning; Strategic Alignment; Performance. 


\section{Sumário}

Lista de Figuras

1. O tema e o problema de estudo 7

1.1. Introdução ao tema e ao problema do estudo 7

$\begin{array}{ll}\text { 1.2. Objetivo do estudo } & 10\end{array}$

1.3. Objetivos Intermediários 10

1.4. Hipóteses ou suposições 10

1.5. Delimitação e foco do estudo 11

1.6. Relevância do Estudo 11

2. Referencial Teórico 12

2.1. Estratégia 12

2.2. Planejamento Estratégico 16

2.2.1. Escolas do Pensamento em Estratégia 18

2.2.2. Estratégias Genéricas 20

2.3. Alinhamento Estratégico 21

3 . Métodos e procedimentos de coleta e de análise de dados do estudo26

3.1. Métodos de pesquisa utilizados 26

3.2. Procedimentos e instrumentos de coleta de dados utilizados no $\begin{array}{ll}\text { estudo } & 27\end{array}$

3.3. Formas de tratamento e análise dos dados coletados para o estudo27

3.4. Limitações do método

4. Apresentação e análise dos resultados 29

4.1. Perfil dos Entrevistados 29

4.2. Análise dos resultados 34

4.2.1. Acompanhamento da Estratégia Formulada 34

4.2.2. Processo de Planejamento Estratégico 35

4.2.3. Colaboradores envolvidos no Planejamento Estratégico 36 
4.2.4. Comunicação do Planejamento Estratégico 37

4.2.5. Eficiência na execução do Planejamento Estratégico 38

4.2.6. Execução da missão corporativa 39

4.2.7. Execução dos valores da companhia 40

4.2.8. A relação dos valores corporativos com os processos de recrutamento e seleção $\quad 41$

5. Conclusões e recomendações para novos estudos 43

5.1. Conclusões sobre a resposta do problema 43

5.2. Conclusões sobre às hipóteses 45

5.3. Recomendações para novos estudos 45

6. Referências Bibliográficas 47

$\begin{array}{ll}\text { ANEXO I } & 49\end{array}$

$\begin{array}{ll}\text { ANEXO } 2 & 51\end{array}$ 


\section{Lista de Figuras}

Figura 1: Estratégias pretendidas, realizadas, deliberadas e emergentes ......... 15

Figura 2: Etapas do Planejamento Estratégico ............................................ 16

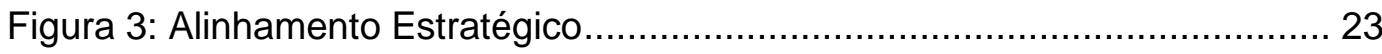

Figura 4: Processo de Alinhamento Estratégico .............................................. 24

Figura 5: Perfil dos Entrevistados - Gênero .............................................. 29

Figura 6: Perfil dos Entrevistados - Idade ............................................... 30

Figura 7: Perfil dos Entrevistados - Graduação ......................................... 31

Figura 8: Perfil dos Entrevistados - Gerência de Equipes .............................. 31

Figura 9: Perfil dos Entrevistados - Participação do Planejamento Estratégico 32

Figura 10: Perfil dos Entrevistados - Áreas Funcionais................................. 33

Figura 11: Perfil dos Entrevistados - Cargos.............................................. 33 


\section{O tema e o problema de estudo}

\subsection{Introdução ao tema e ao problema do estudo}

Ao longo do curso de Administração de Empresas na Pontifícia Universidade Católica do Rio de Janeiro, os conceitos sobre estratégia e seu planejamento foram apresentados e desenvolvidos. As disciplinas abordaram desde a idealização até a sua formalização. Em suma, estratégia é ter a consciência de seu ambiente atual e saber onde, como, quando e porque quer chegar em determinados objetivos. Porém, não foi dado o mesmo enfoque na execução comparado ao dado ao planejamento. Não adianta ter um planejamento excelente se a execução é ruim. E, ao entrar no mercado de trabalho através dos estágios, os alunos percebem que há divergências entre teoria e prática. Diante dessa situação, surge a ideia de entender os porquês disto através deste trabalho aqui iniciado.

Existe controle da execução do Planejamento Estratégico? As estratégias formalizadas pelas empresas são exercidas na prática? Será que o que a empresa se propõe a fazer a respeito de sua estratégia é efetivado? Os colaboradores da empresa sabem qual é a missão, exercem suas atividades baseando-se nos valores da empresa?

Estratégia é um dos conceitos mais utilizados nas organizações para atingir seus objetivos. Utilizam-se recursos internos para aproveitar as oportunidades e por consequência atingir os objetivos. Certo e Peter (1993), argumentam que o grande ágio da gestão estratégica é a integração das áreas funcionais em prol de um objetivo comum, a estratégia da empresa.

Porém, não são todas as empresas que conseguem atingir uma gestão estratégica eficiente, com a execução alinhada com a sua estratégia. Essa situação afeta o desempenho organizacional, estando implícita no dia-a-dia da organização. Não é comum diagnosticar a falta de alinhamento estratégico em uma companhia.

"Não há muitas empresas em que os líderes criariam um novo plano operacional para a maior parte da companhia em dez dias. O que acontece frequentemente é muita conversa e encontros off-site, mas nenhuma ação. Essa é a diferença entre empresas que executam e as que não executam". A citação 
acima de Ram Sharan diz respeito às famosas convenções de elaboração/divulgação do Planejamento Estratégico do ano seguinte das companhias. Este evento é, normalmente, em algum resort com uma estrutura interativa entre a alta direção, de forma a elaborar no final do evento os planos estratégicos para o próximo ano. Ali ficam definidos os principais projetos, mudanças e elementos estratégicos, como missão, visão e valores. Muito dinheiro é investido nesse tipo de evento e, ao final, os executivos saem com a fórmula do sucesso para o ano seguinte. Mas, muitos esquecem que não basta ter a fórmula se ela não é executada da maneira correta. Fazendo uma analogia: se eu tenho um produto excelente, mas não consigo entregá-lo ao meu cliente, a minha empresa é um fracasso.

A falta de alinhamento estratégico faz com que recursos sejam desperdiçados e os processos sejam realizados de forma ineficiente. $O$ desalinhamento estratégico no nível mais alto pode gerar a queda da empresa. Isso geralmente acontece quando a empresa está com alta performance, e seus gestores acham que, por dominar um mercado específico, podem entrar em outros mercados, por exemplo. Então, ao sair da sua estratégia inicial, acabam levando a companhia a queda. Essas situações são detalhadas ao longo do trabalho. Ao final, será compreendido que ter uma estratégia bem definida é um ótimo diferencial competitivo. Agora, manter sua estratégia na prática é um diferencial competitivo maior ainda.

Dificuldades na execução de uma estratégia podem estar ligados as mudanças constantes nos ambientes. Esse fator pode ser amenizado quando se tem previsibilidade dos eventos futuros. A grande diferença entre a execução e o planejamento pode estar no pensamento do líder. Um bom líder não deixa de gerenciar os detalhes de sua companhia, não resume seu trabalho em pensar o que o nível tático irá executar e controlar. Comparando ao futebol, será que um técnico consegue sucesso passando todo o seu tempo no escritório negociando novos jogadores? Com o contato com os atletas, entendendo o ambiente e suas características, buscando melhorá-los, a tendência é o sucesso no desempenho.

Uma empresa se torna grande por obter destaque em algum sentido. Umas são muito inovadoras, outras conseguem otimizar seus custos. Após a conquista de terreno, muitas empresas que chegam ao topo despencam por deixar de lado seus ideais que a levaram ao sucesso. O sucesso realmente muda a cabeça das pessoas, consequentemente muda a cabeça das empresas. Algumas companhias compreendem que deram certo em um determinado mercado, e por isso podem entrar em qualquer outro mercado, que o sucesso 
estará garantido. Mas, na prática não funciona assim. $E$, isso é comprovadamente o motivo da queda de inúmeras grandes companhias. Manter os "pés no chão" vale mais do que tentar "abraçar o mundo".

Empresas pequenas tem menos chance de ter problemas de execução da estratégia, pois, em sua maioria, tem grande sinergia entre os processos e a vitalidade das equipes é fundamental. Assim, há comunicação interna eficiente e consequentemente as chances de cumprimento da estratégia são efetivamente maiores. Por outro lado, como as empresas pequenas buscam crescimento, é bom ter em mente que, ao atingir um maior porte, com maiores recursos, sejam humanos ou financeiros, existe uma tendência de os processos se desalinharem. Muitos funcionários desconhecem a estratégia, alguns conhecem, mas não aplicam no dia-a-dia, e assim por diante.

Muitas empresas pequenas não utilizam as melhores práticas de gestão, e não tem recursos para investir em sistemas integrados que facilitem a gestão, mas crescem por habilidades técnicas. Então, é essencial para as empresas ter, desde seu início, uma estrutura que viabilize a análise dos contextos interno e externo. Assim sendo, o crescimento não desvirtuará o sucesso, fazendo com que o crescimento se perpetue.

Para facilitar o processo de execução da estratégia, Kaplan e Norton (1996) apresentam o Balanced Scorecard, conhecido como "BSC". Esta ferramenta gera sinergia e visão holística no acompanhamento do desempenho organizacional, onde é possível acompanhar resultados financeiros, clientes, processos internos e aprendizado e crescimento. Assim, é possível acompanhar o desempenho da estratégia de forma sistêmica e rotineiramente. Se a organização encarar o planejamento estratégico como um processo contínuo, as chances de sucesso são efetivamente maiores.

Falando especificamente de execução, ela cada vez mais diferencia uma empresa de sua concorrente. As tecnologias evoluem cada vez mais rápido, e, para não ser derrotado, é necessária eficiência na execução. Ter uma inovação em mãos é excelente, um grande passo para o sucesso. Mas, se essa inovação não for bem executada não haverá sucesso. Execução é uma tarefa conectada ao planejamento. A ideia de que os executivos planejam o futuro da companhia e os funcionários do nível tático executam é ultrapassada e equivocada. Execução é sim uma tarefa estratégica. Um bom líder sabe executar da forma correta.

O líder deve se envolver em todos os pontos do seu negócio e ser transparente de dentro para fora. Não adianta haver planejamento, equipes 
caríssimas, metas arrojadas, bonificações gordas, se não há execução. Se a empresa XPTO se compromete a atingir um resultado e ao final do período não consegue atingi-lo, o próprio mercado reagirá. Nesse caso, a "culpa" não é necessariamente da formulação da estratégia. Mas esta não é, na maioria das vezes, a causa. Uma estratégia tem mais chance de sucesso quando bem executada. Caso contrário, a teoria fica distante da prática.

Afinal, a execução da estratégia corporativa é realmente alinhada com o seu planejamento?

\subsection{Objetivo do estudo}

O objetivo deste estudo é identificar o ponto de vista de executivos sobre a execução da estratégia corporativa planejada das empresas em que estes trabalharam ou trabalham. Busca entender o que ocorre nos casos onde a execução não foi bem-sucedida, e que fatores são importantes para que a estratégia seja executada de acordo com o planejado, absorvendo, logicamente, mudanças fundamentais no mercado. Essas questões foram debatidas e ao final as respostas encontradas foram expostas.

\subsection{Objetivos Intermediários}

- Identificar se há alguma ferramenta de controle da execução do Planejamento Estratégico;

- Identificar as possíveis lacunas entre execução e planejamento da estratégia;

- Identificar medidas que melhorem a eficiência da execução do Planejamento Estratégico.

\subsection{Hipóteses ou suposições}

Ao longo da vivência corporativa em que os alunos do curso de Administração da PUC-Rio participam nos estágios de complementação de graduação, estes passam a associar as teorias aprendidas nas salas de aula da PUC-Rio com a prática exercida nos estágios. Afinal, o grande objetivo do estágio é complementar a graduação com a prática do dia-a-dia de uma 
empresa. É muito comum haver frustração dos estudantes de Administração quando este sai da teoria e se aproxima da prática. $\mathrm{O}$ maior fato para isto é o descasamento entre o que é ensinado e o que efetivamente é praticado no diaa-dia (consultar artigo do Anexo I para maiores informações).

Então, por experiências ouvidas, a maioria das empresas não executa sua estratégia da forma planejada. E, o processo de Planejamento Estratégico é, em sua maioria, uma necessidade para se fazer presente no mercado principalmente para empresas de capital aberto, que precisam dar uma posição aos seus acionistas. Quem não tem uma missão declarada em seu site e na recepção das sedes da empresa, automaticamente está fora do mercado, pois não é "transparente".

\subsection{Delimitação e foco do estudo}

A pesquisa se limita a visão de executivos ou ex-executivos de diferentes mercados no Rio de Janeiro. Os diferentes pontos de vista serão descritos e analisados, destacando os pontos fortes de cada tese e os diferenciais entre si. É importante levar em consideração o período em que essa análise foi feita, entre setembro de 2015 e maio de 2016. Não será avaliada a eficiência da formulação do Planejamento Estratégico, e sim a execução desta.

\subsection{Relevância do Estudo}

Este estudo contribui com a formação acadêmica dos alunos de graduação de Administração de Empresas da PUC-Rio. Nele, é possível dissertar sobre diversos temas vivenciados no curso. Este tema é de devida importância, pois não há muitos estudos a respeito de alinhamento estratégico. A importância deste tema é demonstrada neste estudo, propondo soluções para a presença do desalinhamento. Em tempos de austeridade, toda a companhia deve estar alinhada para que haja eficiência na execução de seus processos-chave.

O estudo é importante também para a academia, definindo ou lapidando os conceitos pré-estabelecidos. É relevante também para os gerentes e as empresas, já que pretende melhorar os processos de execução do Planejamento Estratégico. 


\section{Referencial Teórico}

\subsection{Estratégia}

O vocábulo estratégia está ligado ao termo grego strategia, que remete ao comando do exército. Assim, é possível associar com as batalhas da época de Alexandre, o Grande, por exemplo. Estratégia não é um conceito novo. Sun Tzu foi um grande difusor do conceito de estratégia. Sua obra "A arte da guerra" foi escrita durante o século IV a.C. Daí, podemos entender que estratégia é utilizada anteriormente à estratégia corporativa, sendo um conceito histórico no mundo das guerras. Sun Tzu, em seu tratado, resumiu alguns princípios básicos de uma boa estratégia:

- Fugir do conflito, minimizando o desgaste;

- Princípio da Massa, concentrando sua força no local e momento precisos de necessidade;

- Organização e planejamento.

$\mathrm{Na}$ verdade, ali nascia a arte de administrar. Como gerenciar um batalhão de milhares de pessoas, sem praticamente nenhuma tecnologia, comparado a hoje? Como planejar a quantidade de suprimentos necessário para seu batalhão e seus cavalos para uma guerra? A estratégia em seu planejamento responde.

Em meados da década de 1950, no contexto americano do pós-guerra, o mundo corporativo passou a utilizar o termo estratégia no seu escopo, visto que as mudanças eram constantes e aceleradas, demandando algum diferencial competitivo. Analistas e professores passaram a procurar casos de sucesso e tentar padroniza-los para "vendê-los" como produto para alcançar seus objetivos corporativos.

Em 1959, Edith Penrose, autora de livros de economia lança o livro "A Teoria do Crescimento da Firma". Ele inspirou muitos especialistas de administração a dissertar sobre as influencias das empresas na economia. Penrose diz que uma empresa não é uma caixa preta e que o ambiente externo é um grande fator de análise, tocando no ponto de estratégia.

Andrews (1971) conclui estratégia corporativa como modelo de decisão corporativa onde os objetivos e planos são traçados, delimitando até onde o 
negócio atuará. Com o tempo, o conceito de estratégia vai se aperfeiçoando e sendo difundido.

Para Mintzberg (1983), estratégia é uma adaptação entre as operações estáveis com o dinamismo, proporcionando uma organização dinâmica e eficiente simultaneamente.

Quinn (1992), define estratégia como um modelo que une os objetivos da companhia às suas ações e regras.

Para Porter (1996), estratégia é a definição de um conjunto de atividades para proporcionar valores únicos.

Henderson (1998) define estratégia como buscar continuamente dentro de um planejamento desenvolvido vantagem competitiva para a companhia em questão.

Estratégia é um plano de ação para alcançar determinado objetivo, ou seja, é você saber o que quer, onde está e definir o caminho para onde quer chegar. As organizações cada vez mais evoluem, em busca de novas estratégias para alcançar o crescimento ou para se manter no mercado

O conceito de estratégia é constantemente repetido no mundo dos negócios. Faz parte do planejamento de um novo negócio ou mesmo da gestão de um negócio já existente. A partir disso, estratégia deve ser considerado um diferencial competitivo. Ou seja, quem exerce sua estratégia da forma correta de acordo com o que foi anteriormente alinhado - tem maior chance de alcançar seus objetivos da forma mais eficiente.

Michael Porter disse que a estratégia é "mais importante do que qualquer projeção de crescimento de mercado". Com essa frase, ele quis dizer que as empresas não devem focar em atingir o lucro, e sim nos meios na qual o lucro é atingido. Se a empresa tiver a fórmula certa, será questão de replicação da estratégia com adaptações ao cenário.

Wheelwright (1984) divide o conceito de estratégia em três categorias: corporativa, do negócio e funcional. A estratégia corporativa influencia a empresa como um todo, com base em seus ambientes interno e externo.

Tachizawa (2006) divide a estratégia em quatro elementos: produtos a serem produzidos ("o quê"); clientes ("para quem"); vantagens frente aos concorrentes ("por quê"); e mercados ("onde”). Em seguida, Tachizawa define diferentes tipos de estratégicas genéricas de acordo com seu setor econômico.

Já a estratégia de negócio também é conhecida como estratégia competitiva. Para Porter (1980), estratégia competitiva são ações ofensivas ou defensivas para criar uma posição defensável numa indústria, para enfrentar 
com sucesso as forças competitivas e assim obter um retorno maior sobre o investimento. Ou seja, a estratégia definirá como a concorrência será vencida.

As estratégias funcionais são específicas a cada área funcional da empresa (recursos humanos, financeiro, marketing, etc.), devendo ter um foco em comum, de modo a não ir contra a estratégia corporativa. A estratégia competitiva é a união das estratégias funcionais, de forma que se houver silos entre as áreas, característica de empresas tradicionais, é provável que haja distorções no resultado da estratégia. Por exemplo, uma empresa com estrutura funcional deve alinhar o público-alvo do marketing com o comercial. Se as áreas optarem por estratégias funcionais distintas, haverá problemas na operação.

É importante não confundir estratégia com eficiência operacional. Para vencer a concorrência, a empresa deve possuir um diferencial explícito, criando um maior valor ao consumidor ou sendo líder por custos, por exemplo. Eficiência operacional é algo que não gera diferenciação, porque com o tempo todos serão eficientes, levando todos os concorrentes para o mesmo caminho, sem nenhum se destacar.

Nesse cenário de diferentes definições, Mintzberg (2000) afirma que estratégia não é apenas uma definição e sim uma série de definições. Nesse momento, são apresentadas diferentes aplicações de estratégia, os 5 P's: plan, pattern, position, perspective e ploy, traduzidos livremente como: planejar, padronizar, posicionar, perspectiva e estratagema, respectivamente. É importante destacar ao leitor o conceito de estratagema. Trata-se de um componente estratégico, utilizado em ambiente militar normalmente, de forma a mitigar e/ou enganar o inimigo.

Planejar e padronizar, os dois primeiros Ps, estão intimamente ligados ao processo de elaboração e execução da estratégia. Se a estratégia planejada (pretendida) for diferente da implementada (realizada), parte do plano de ação não foi executado. As ações não executadas constituem a estratégia não realizada, devido a não fazerem parte da prática. A figura a seguir ilustra essa situação. 


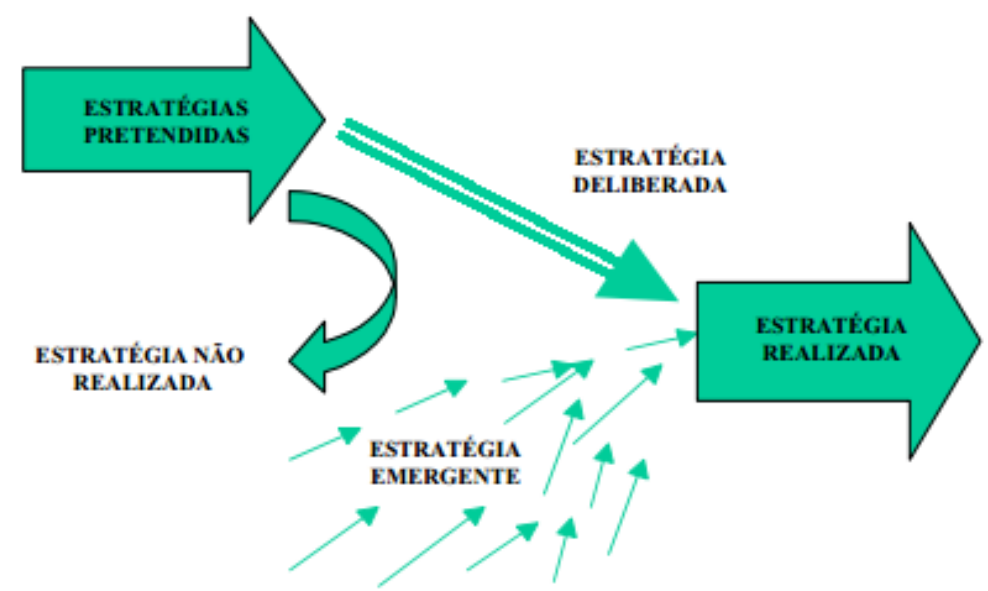

Figura 1: Estratégias pretendidas, realizadas, deliberadas e emergentes Fonte: Mintzberg e Quinn (2001)

De outro lado, a estratégia implementada (realizada) pode incluir ações não planejadas na planejada (pretendida). Mintzberg define essas ações como estratégia emergente, derivada do conhecimento externo ao ambiente ou da operação do dia-a-dia, de modo a atingir a excelência operacional. Então, a estratégia realizada é a soma das estratégias pretendidas e a estratégia emergente.

Os conceitos de posicionar e perspectiva, terceiro e quarto Ps, estão relacionados entre si assim como os dois primeiros Ps. Mintzberg (2000), apresenta o exemplo do lançamento do Egg McMuffin pelo McDonald's em 1972 para explicar esses conceitos. Se este lançamento for encarado como um lançamento de um produto para o café da manhã, mercado na qual não atuava, alterando a estratégia anterior, o conceito adotado é o de posicionar. Se o lançamento for visto como uma continuidade da estratégia anterior, o conceito adotado é o da perspectiva. Neste conceito, a empresa não modificou a forma dos seus produtos, apesar de ter entrado no "mercado de café-da-manhã". Neste caso, o McDonald's já tinha a capacidade de vender este produto, apesar de não o fazer.

O último $\mathrm{P}$ refere-se à elaboração de táticas para mitigar a ação dos concorrentes. 


\subsection{Planejamento Estratégico}

Planejamento Estratégico é o processo de elaboração da estratégia corporativa, na qual se define a relação entre a organização e o ambiente interno e externo, bem como os objetivos organizacionais, com a definição de estratégias alternativas (MAXIMIANO, 2006).

A base do planejamento estratégico passa por responder algumas perguntas:

- Quem somos?

- Qual a nossa missão?

- Onde queremos chegar?

- Como iremos chegar onde queremos?

A partir dessas respostas, a missão e a visão estão respondidas. O próximo passo é analisar o ambiente interna e externamente. Uma boa forma de entender o ambiente é através da matriz SWOT ou do Modelo das 5 forças de Porter, analisando as oportunidades e ameaças do setor. Com o setor mapeado, é possível enxergar o caminho a seguir. É nesse momento que as metas e objetivos são formulados até chegar na estratégia em si. Além da execução, o controle é essencial para que todo o processo seja eficiente. Caso houver algum desvio, ele será corrigido nesta etapa.

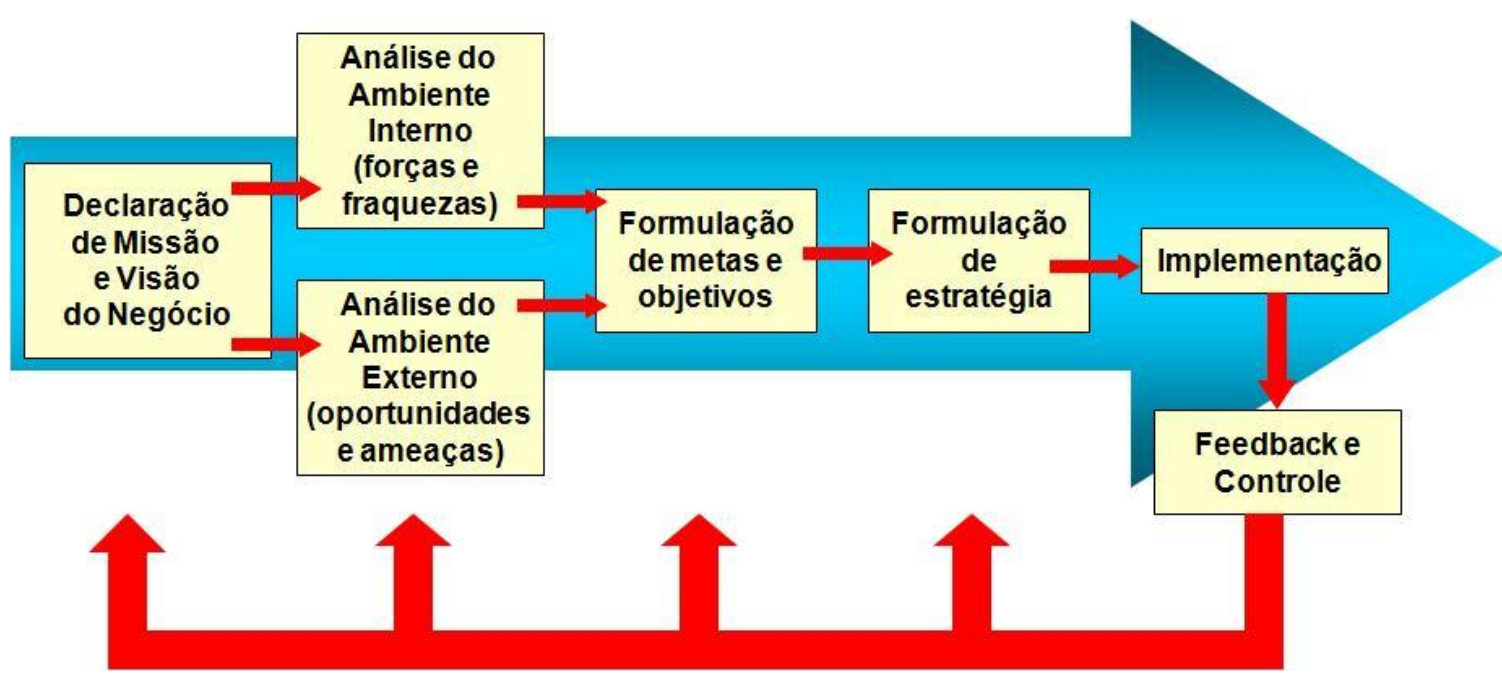

Figura 2: Etapas do Planejamento Estratégico

Fonte: Kotler (1999)

Segundo CHIAVENATO (2004), estas etapas apresentadas englobam as cinco principais partes do processo estratégico.

1. Concepção Estratégica; 
2. Gestão do conhecimento estratégico;

3. Formulação estratégica;

4. Execução da estratégia;

5. Avaliação da estratégia.

A estratégia aponta o caminho. O planejamento estratégico indica como andar por ele (CHIAVENATO \& SAPIRO, 2004).

O Planejamento Estratégico ganha cada vez mais importância. Com a intensificação da concorrência, cada detalhe pode ser o diferencial para criar diferenciação. Um desses detalhes é o planejamento estratégico. Se bem planejado, executado e controlado, a estratégia pode garantir vantagem competitiva.

A estratégia deve "descer" da alta diretoria para a operação da companhia. Para a elaboração de uma estratégia formal, devem ser usados conceitos como a Matriz BCG (PORTER, M.). Os elementos para a elaboração de uma estratégia formal são:

- Visão;

- Missão;

- Objetivos;

- Metas;

- Políticas;

- Regulamentos;

- Orçamento.

Há diversos tipos de definições para gestão estratégica. Peter e Certo (1996) definem administração estratégica como "um processo interativo que visa manter uma organização como um conjunto apropriadamente integrado ao seu ambiente". Outros autores como Ansoff e McDonnel (1993), Mintzberg et al. (2001) e Pettigrew e Whipp (1993) concordam que a gestão estratégica eficaz necessariamente integra a companhia ao seu ambiente, mantendo-a competitiva em longo prazo.

Porém, há algumas discordâncias quanto ao como as organizações conduzem seus processos de gestão estratégicas. Mintzberg (1987), Prahalad e Hamel (1990) e Quinn (1980) defendem que não há separação entre planejamento e execução de uma estratégia. Já Certo e Peter (1993), Ansoff (1965) e Kaplan e Norton (2000) definem o processo de gestão estratégica como processos diversamente desintegrados, como análise dos ambientes, formulação da estratégia, execução da estratégia e controle estratégico. 
Mintzberg adota quatro abordagens distintas para atingir a competição necessária. O "porteriano", homenagem a Michael Porter, foca na análise do ambiente externo, identificando os mercados mais atraentes. Já a abordagem "peteriana", homenagem a Tom Peters, aposta em cultura e valores fortes, permitindo a companhia se diferenciar e enfrentar melhor os momentos de crise. A terceira abordagem é a contextualista, baseado nos autores Pettigrew e o próprio Mintzberg. Essa abordagem baseia a gestão estratégica em contexto, conteúdo e um processo. O contexto se refere aos ambientes (interno e externo), o conteúdo busca alinhar o contexto interno e externo e o processo é como executar as decisões e como executá-las. A última abordagem é a "prahaladiana", homenagem a Prahalad, que prega que o sucesso competitivo está na ausência de padrões. Ou seja, o caminho é criar sempre novos padrões, tanto para a formulação da estratégia - seu conteúdo em si - quanto para como execução.

\subsubsection{Escolas do Pensamento em Estratégia}

Segundo Henry Mintzberg, a administração estratégica pode seguir algumas escolas (MINTZBERG, 2000). Essas escolas são guias genéricos que auxiliam o processo de planejamento da estratégia. A seguir apresento o conceito de algumas delas.

As Escolas Prescritivas - Escola do Design, Escola do Planejamento, Escola do Posicionamento - tem por característica separar a formulação da estratégia de sua execução

As Escolas Descritivas - Escola Empreendedora, Escola Cognitiva, Escola do Aprendizado, Escola do Poder, Escola Cultural e Escola Ambiental - se preocupam com a descrição da execução e formulação da estratégia.

Na Escola do Design a estratégia é tratada como uma concepção, sendo "criada" a partir de uma avaliação do ambiente (interno e externo). O responsável pela criação é o principal executivo da empresa, seu CEO. É importante que as estratégias definidas sejam simples e explícitas.

Sua ferramenta básica é a análise SWOT, definindo suas forças, fraquezas, oportunidades e ameaças. A conclusão do ambiente externo (oportunidades e ameaças) dará origem aos fatores críticos de sucesso. Já no ambiente interno (forças e fraquezas) serão identificadas as competências 
distintivas da organização, capazes de gerar vantagem competitiva frente aos concorrentes.

A Escola do Planejamento é considerada a continuação da escola do Design. Ambas utilizam a premissa de que a estratégia deve ser fruto de uma análise dos ambientes. A grande diferença da escola do Planejamento é que esta fornece um grau de padronização mais elevado. Rotinas de check-up, manuais de procedimentos estratégicos garantem essa diferenciação, que não são vistos na escola do Design. Tamanha formalidade criou a função de planejador, diminuindo a responsabilidade do poder do principal executivo da companhia. Ao contrário da escola do Design, o executivo apenas aprova a estratégia definida.

A Escola do Posicionamento utiliza métodos semelhantes aos das escolas do Design e Planejamento. Na escola do Posicionamento, a estratégia é um processo analítico. É feita uma análise com base em uma série histórica, a fim de planejar o próximo ano. Esta escola foi influenciada por Michael Porter, efetivando a teoria das "Cinco forças de Porter". A empresa deve entender a indústria que está inserida e encontrar a posição que lhe garantirá a melhor performance, levando sua organização para esta direção.

A Escola do Posicionamento separa a formulação da execução, da mesma forma que o papel do principal executivo da elaboração da estratégia. Assemelha-se nesse ponto à escola do Planejamento, sendo responsabilidade dos analistas a elaboração da estratégia e o executivo com sua aprovação. Um ponto negativo desta escola é a distância daqueles que formulam a estratégia, os analistas, apenas com visão operacional da companhia, e dos que executam a estratégia, os gerentes, que não participaram efetivamente de sua elaboração.

As Escolas descritivas começam com a escola empreendedora. Tem essência diferente das escolas do design, planejamento e posicionamento, sem se preocupar com a execução da estratégia. A preocupação desta escola é com a formulação da estratégia, realizada pelos principais executivos da empresa. Quem formula a ideia é o empreendedor, que é não necessariamente o detentor do capital, mas sim o idealizador do projeto. (Schumpeter, 1950)

Para Mintzberg (2000), na escola empreendedora a estratégia é liderada de forma quase que obsessiva pelo empreendedor. A mente do líder rege a estratégia, com uma visão de futuro da companhia. O empreendedor deve identificar onde está a oportunidade, como aproveitá-la, quais recursos são necessários, como eles são adquiridos e qual estrutura deve ser utilizada. 
Na Escola Cognitiva, a estratégia é um processo cognitivo, estando presente na mente de seu formulador. Faz-se o uso da psicologia cognitiva e do construtivismo, onde tudo depende do "Mapa Cognitivo" do autor da estratégia. Por isso, há dificuldade em obter qualidade na formulação da estratégia. Com base nesta escola, uma análise SWOT tem apenas oportunidades, ameaças, forças e fraquezas que seus formuladores imaginam que sejam reais.

Na Escola do Poder, a estratégia é um processo de negociação, através do poder. Empresas são fusões de diversos indivíduos e diversos grupos de interesse. Por isso, as metas e cargos são formuladas através de negociações com o objetivo de atender as diferentes posições. Nesta escola, os argumentos técnicos são essenciais para atingir seus objetivos, visto que há inúmeros stakeholders e estes acabam por complicar a governança corporativa. Assim, governança se torna uma vantagem competitiva. A adoção de uma determinada estratégia é considerada uma vitória de poder sobre as outras.

$\mathrm{Na}$ Escola do Aprendizado, a estratégia é um processo emergente, que percorre ao longo do tempo. Neste caso, o aprendizado estratégico é utilizado para que os pré-conceitos sejam eliminados. Assim, as decisões se acertam de acordo com o momento. Como nem sempre há um grande líder para inspirar a visão da empresa, elas podem construir sua estratégia levando em conta o dinamismo do dia a dia e as diversas opiniões. Nesta escola estão as maiores críticas sobre as escolas prescritivas.

A grande preocupação dessa escola é com a formação da estratégia, deixando claro que é impossível separar a elaboração da execução. Sobre esse ponto de vista é impossível uma estratégia fracassar, é impossível haver falha de formulação ou de execução. Se a estratégia for realmente eficaz, ela terá sucesso. Erros de execução tem origem nas análises equivocadas de macro ambiente, superestimando seu ambiente interno ou subestimando o ambiente externo.

\subsubsection{Estratégias Genéricas}

Tachizawa (2006) define elementos estratégicos genéricos determinados por certo setor econômico e atividade de negócio. Cada um desses, segundo o autor, possui determinadas características que possibilitam tomar certa estratégia com melhor sucesso. 
Porém, Tachizawa define estratégias genéricas usadas para obter vantagem competitiva perante a concorrência. São formas pré-estabelecidas de superá-los. Podem ser de liderança no custo, diferenciação e foco. Na prática, a ideia é encontrar um meio termo entre essas estratégias e aplicá-los na companhia desejada.

A estratégia de liderança no custo tem como base a obtenção de menores custos perante a concorrência. Normalmente, os maiores players do mercado conseguem se diferenciar por custo, já que conseguem comprar em maior quantidade e consequentemente por um preço menor. Esse poder de barganha com os fornecedores gera uma possibilidade de cobrar maiores preços, ou simplesmente aumentar a margem de lucro. Além disso, os riscos diminuem já que os custos são reduzidos.

Já a estratégia de diferenciação necessita de algum produto ou serviço inédito no mercado. Assim, apenas essa empresa poderá vendê-lo. Se alcançada, essa estratégia pode fazer com que a empresa controle o preço de venda, já que apenas ela detém a tecnologia. $E$, outra consequência é a alta parcela do mercado adquirida pela empresa, vide Apple e Samsung. Além disso, essa estratégia gera fidelidade do cliente a marca.

A estratégia de foco consiste na empresa concentrar seus esforços em uma determinada parcela da população. É uma combinação entre a estratégia de diferenciação e a estratégia por custos, atingindo um público consumidor específico.

Após apresentar as estratégias genéricas, Tachizawa apresenta estratégias para os oito setores econômicos por ele definidos (consultar Organização Flexível: Qualidade na Gestão por Processos).

\subsection{Alinhamento Estratégico}

"Executar não é algo que se consegue ou não se consegue fazer. É um conjunto específico de comportamentos e técnicas que as empresas precisam dominar para terem vantagem competitiva. É uma disciplina por si só. Em grandes e pequenas empresas, é atualmente a disciplina principal para se atingir o sucesso. " (BOSSIDY \& CHARAN, 2005)

O passo seguinte do Planejamento Estratégico é o Alinhamento Estratégico. A estratégia é debatida e o plano estratégico é confeccionado. 
Agora, é necessário garantir que a estratégia será cumprida, através de um controle da execução.

Uma excelente forma de "descer" o planejamento do topo para a base da pirâmide organizacional é através de uma boa comunicação na empresa. É primordial que todos sejam envolvidos nesse processo. Caso contrário, o planejamento estratégico estará prejudicado e há tendência de desperdício de recursos. Para isso, são necessários processos de comunicação eficientes, com trabalho em equipe, autonomia e liberdade dos colaboradores, havendo melhoria contínua nestes elementos.

Em muitos casos, o Planejamento Estratégico é feito por uma empresa terceirizada, que se instala no cliente e faz o mapeamento do ambiente, desenvolvendo todo o plano estratégico. Depois de aprovado e entregue o resultado, a equipe se retira da companhia. Isso é um ponto de atenção para o controle da execução da estratégia. É necessário ter uma equipe interna para garantir que os processos formalizados serão cumpridos.

Um bom planejamento estratégico gera novos sócios através da venda de ações - no caso de empresas de capital aberto. Se o planejamento não for cumprido, trata-se de uma "propaganda enganosa". Isso é caso de falta de governança corporativa.

O Alinhamento, como etapa pós planejamento, deve ser tratada com a mesma importância da etapa anterior. É crucial para guiar a companhia nas direções pré-estabelecidas. Do que adianta ter um carro se não há quem o dirija? A base desse processo é liderança e comunicação. Por isso, não é um processo custoso como o planejamento. O investimento nessa etapa gerará equipes mais motivadas, com um ganho imenso de performance.

O Alinhamento Estratégico funciona como um imã da organização, orientando seus processos para a direção formulada. No caso da figura a seguir, a seta maior é a estratégia formulada e as menores são as atividades executadas pelos agentes da empresa. Quando há alinhamento entre elaboração e execução estratégica, tudo ocorre na mesma direção. 


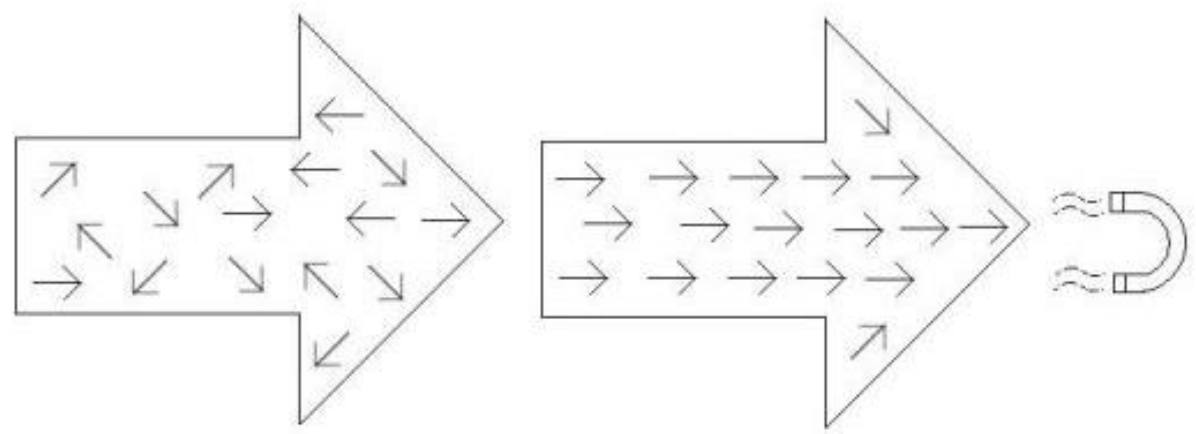

Figura 3: Alinhamento Estratégico

Fonte: CORRÊA (2008)

Kaplan e Norton (2000) dissertam que a capacidade de executar as estratégias formalizadas é o grande problema relacionado à gestão estratégica de uma organização. Apesar das empresas conseguirem formular estratégias teoricamente boas, elas não conseguem desempenhá-las, pelo fato de seus processos internos não permitirem uma boa execução.

Já Mintzberg (2000) acredita que é uma ilusão haver uma lacuna entre elaboração e execução da estratégia. Para ele, uma estratégia boa jamais deixaria de ser executada se realmente fosse boa. Havendo problemas na execução, é provável que alguns pontos fortes tenham sido valorizados em excesso ou ameaças não foram levadas em consideração.

Mietto afirma que há três razões para não se ter alinhamento estratégico: falta de visão, falta de processos alinhadores ou falta de disciplina. Na falta de visão, os líderes não se importam ou não conhecem o ambiente desalinhado da companhia. Na segunda razão, há vontade de que haja alinhamento, porém, os processos são extremamente desalinhados, não proporcionando o cumprimento da vontade. A falta de disciplina é quando há inicialmente controle do alinhamento, mas com o tempo este é perdido.

Mietto prossegue na análise, afirmando que são necessárias duas condições para haver alinhamento estratégico: utilização de processos estruturados na sua execução e o comprometimento dos colaboradores nessa missão. Após isso, o autor divide o processo de alinhamento estratégico em seis etapas, seguindo a seguinte ordem: comunicação interna, elaboração da missão, definição de pilares estratégicos, definição dos projetos chave, elaboração de planos de trabalho alinhados e estabelecimento de avaliações de desempenho periódicas, ilustradas na figura a seguir. 


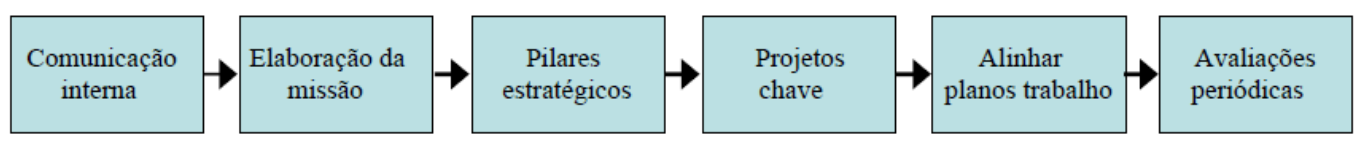

Figura 4: Processo de Alinhamento Estratégico

Fonte: Mietto.

O Alinhamento Estratégico inicia-se ao comunicar a todos os funcionários o que é, suas etapas e seus benefícios. É importante que a primeira comunicação seja feita fisicamente, via apresentações e discursos. Isso contribui para criar um clima cooperativo entre os colaboradores. A comunicação deve ser mantida ao longo das demais etapas do processo, seja via intranet, e-mails ou qualquer outro modo. A elaboração da missão visa expressar para que a empresa existe, onde e como ela quer chegar. Os valores da companhia devem estar presentes na elaboração da missão, demonstrando as razões emocionais para a existência da empresa. Por que existimos? Onde queremos chegar? 0 que é importante para nós? Perguntas como essas devem ser respondidas. Muitas vezes este processo é comandado por uma consultoria especializada.

Os pilares estratégicos são motivações da empresa que levam o negócio na direção da sua missão, pontos de atuação presentes e previsão de necessidades futuras. A definição dará origem a estratégia operacional, que levará a todas as atividades da empresa. O que é necessário para atingir a missão? O que devemos fazer para garantir o negócio no futuro? Essas perguntas devem ser respondidas nessa etapa. Os pilares estratégicos darão origem aos projetos chave, que como o próprio nome diz são os mais importantes para o andamento da companhia. Devem ser de fácil compreensão e mensuráveis para que possam ser medidos ao longo do tempo, e deve ser conduzido pelos melhores colaboradores da companhia. É importante que os projetos sejam acompanhados pela alta diretoria. Sempre pode haver barreiras ao sucesso da execução. Portanto, com o acompanhamento da diretoria, os obstáculos podem ser superados.

A etapa de planos de trabalho tem alta importância porque garante 0 alinhamento das atividades na ponta. Com o plano de trabalho padronizado, os pilares estratégicos guiarão o desenvolvimento das atividades. Qualquer atividade que não se encaixar no pilar estratégico deve ser excluída do escopo dos planos de trabalho. Assim, com base em um pilar estratégico, é criado um plano de trabalho. Por exemplo, se uma companhia tem um pilar estratégico de aumentar os lucros em X\%, uma atividade possível para um gerente pode ser de 
reduzir os custos operacionais de sua área em X\%. Ainda nessa etapa, após a definição dos planos de trabalho com base nos pilares estratégicos, é importante que todos os planos de trabalho sejam divulgados para evitar que haja duplicidade nas atividades. Esse papel pode ser do $\mathrm{RH}$.

A última etapa - e não menos importante - são as avaliações periódicas. Mietto sugere que o acompanhamento seja feito quatro vezes ao ano, segregado entre três reuniões entre chefe e subordinado ao final de cada trimestre, e uma reunião de avaliação de performance no final do ano. Essas reuniões afastam dúvidas ou desvios em alguma etapa do Alinhamento Estratégico. A disciplina dessa etapa pode parecer exaustiva, segundo o autor. Mietto afirma que um gestor com sete liderados, por exemplo, usará no máximo 48 horas nesse processo, correspondente a $2 \%$ do tempo total.

O ciclo - pois é um processo sem fim - de Alinhamento Estratégico se encerra nesta etapa. Mietto recomenda que estes processos sejam revistos anualmente. 


\section{Métodos e procedimentos de coleta e de análise de dados do estudo}

\subsection{Métodos de pesquisa utilizados}

A pesquisa é teórico-empírica. É teórica pois, como o nome já diz, busca entender se a teoria se relaciona com a prática. E, empírica pois o pesquisador usou dados obtidos através da experiência própria relacionados a opinião de executivos de corporações brasileiras. A coleta de dados foi qualitativa, com o aprofundamento das questões relacionadas ao tema da pesquisa. Foi incluído um resumo do perfil dos entrevistados na avaliação das entrevistas, para fazer analogias na conclusão com alguns pontos fáceis de serem mensurados, como idade, por exemplo, e o processo de Planejamento Estratégico, quantificando os dados. Porém, a da entrevista foi qualitativa.

A coleta qualitativa permite que não haja uma pesquisa padronizada, porque os respondentes têm liberdade para responder o que pensam, já que o questionário não é rigidamente estruturado. Assim, foi possível extrair maiores informações do entrevistado, que muitas vezes podem levar o entrevistador a enxergar pontos inimagináveis.

Marconi (1991), relata que a entrevista é uma das melhores fontes de obtenção de informação. Podem ser espontâneas, estruturadas, desestruturadas, focal ou com grupo de enfoque. Esta pesquisa é semiestruturada, pois, há um roteiro a ser seguido, mas no momento da entrevista houve variações nas questões apresentadas. Isso varia com a criatividade e a perspicácia do entrevistador, capaz de extrair a maior quantidade de informação possível dos seus entrevistados.

Os pontos fortes da entrevista são o enfoque direto no tema estudado (direcionada) e a capacidade de extrair informações externas relevantes (perceptiva). Já os pontos fracos são a visão tendenciosa - no caso de questões mal formuladas, que levam o entrevistado a responder mediante a opinião do entrevistador - as respostas tendenciosas - pois, dependendo do tema, o entrevistado pode não querer expor a verdade - e a possibilidade de haver falta de informações por falta de memória do entrevistado. 


\subsection{Procedimentos e instrumentos de coleta de dados utilizados no estudo}

"O elemento mais importante para a identificação de um delineamento é o procedimento adotado para a coleta de dados. " (GIL, 1999)

Nesta pesquisa, foram entrevistados (as) dez executivos (as) com histórico de gestão de equipes e com participação no Planejamento Estratégico de suas empresas. Ao se desenvolver a análise dos dados coletados, sentiu-se a necessidade de entrevistar colaboradores que não haviam participado do processo de Planejamento Estratégico, de modo a entender como estes vivenciaram tal processo e receberam as informações. Após o levantamento dos dados, foi preparado um relatório final com as conclusões a respeito do problema levantado.

O relatório de análise foi dividido entre o perfil dos entrevistados e a análise dos dados qualitativos. No perfil dos entrevistados, foram levantadas as características das pessoas como idade, gênero entre outros. A identidade dos entrevistados e suas empresas foram preservadas. Após o perfil dos entrevistados, foram delineados os resultados das respostas dos executivos.

\subsection{Formas de tratamento e análise dos dados coletados para o estudo}

Os dados desta pesquisa foram coletados em fontes primárias, através de entrevistas/questionário. Os dados primários foram comparados a dados secundários dissertados no capítulo 2 , de forma a comparar a realidade apresentada pela pesquisa com as teorias. O roteiro das entrevistas está detalhado no Anexo II, ao final deste trabalho.

O tratamento dos dados foi qualitativo, necessário nos estudos de caso. A análise dos dados primários coletados nas entrevistas foi confrontada com teorias de pensadores sobre o assunto e vivências do autor desta pesquisa, dando origem a conclusão desta dissertação. 


\subsection{Limitações do método}

Dentre as limitações desta pesquisa, destaca-se o fato de que não é possível generalizar suas conclusões. Cada organização tem suas peculiaridades, com diversas lacunas entre si. Essas lacunas podem existir devido a condições econômicas, região geográfica, setor da empresa, públicoalvo, tamanho da empresa, entre outros. Nesta pesquisa foram entrevistados (as) dez executivos (as) de diferentes setores, com faixa etária variada, sendo todos brasileiros. Portanto, não se poderá generalizar as conclusões desta pesquisa para qualquer empresa de qualquer setor e qualquer nacionalidade.

Outra limitação desta pesquisa, destacada pelo fato de ser qualitativa, é o caráter atemporal das conclusões. A pesquisa foi realizada em 2016. Então, as conclusões são aplicadas a este período. Anos anteriores e subsequentes não podem ser explicados pelas conclusões deste estudo. 


\section{Apresentação e análise dos resultados}

\subsection{Perfil dos Entrevistados}

O ritual de pesquisa se iniciou com perguntas para traçar um perfil dos entrevistados. Assim foi possível fazer análises mais profundas sobre determinado perfil. Para tal análise, os dados foram adaptados para uma análise quantitativa, resumidas em sete pontos: idade, gênero, graduação, gerência de equipe, participação da elaboração do Planejamento Estratégico, áreas funcionais e cargos.

O gênero sexual dos entrevistados foi dominantemente masculino, seguindo proporção a seguir. Isto é um reflexo da dominância masculina nos ambientes corporativos, que ao longo dos anos vem diminuindo. Dos 10 entrevistados, 9 são homens e 1 é mulher.

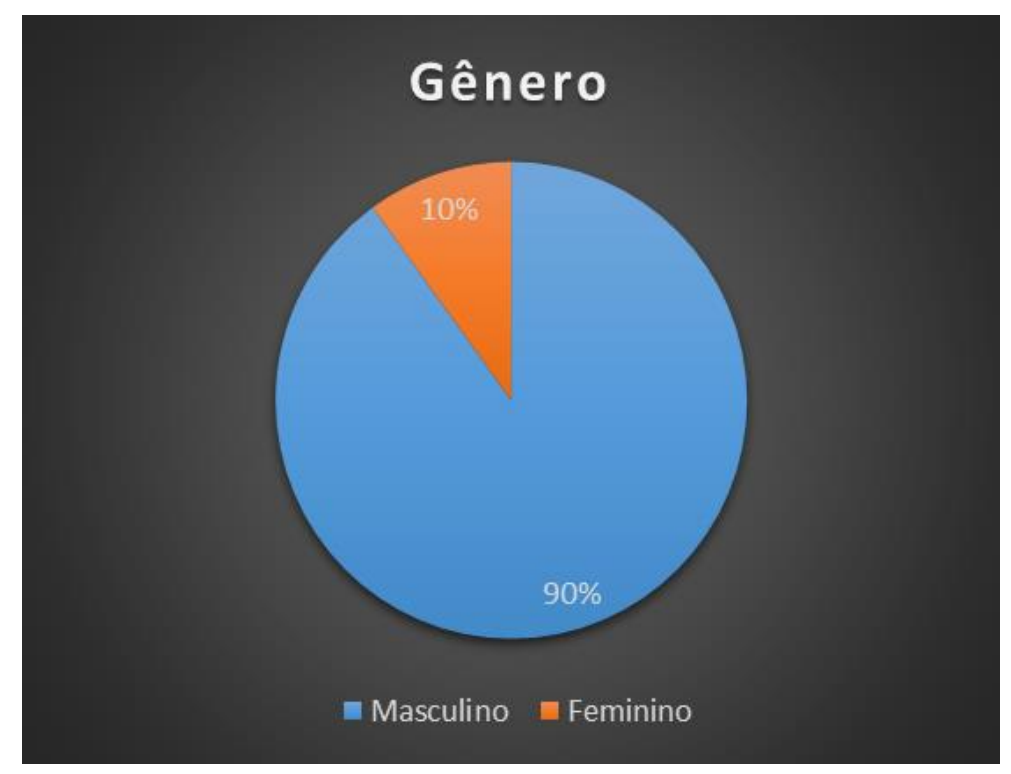

Figura 5: Perfil dos Entrevistados - Gênero

Os executivos entrevistados tem as idades discriminadas a seguir. É notável que as idades são variadas, podendo chegar a analogias na conclusão a respeito deste tema. A idade média foi de 36,8 anos. 


\begin{tabular}{|l|r|}
\hline Entrevistados & Idade (anos) \\
\hline Entrevistado 1 & 26 \\
\hline Entrevistado 2 & 49 \\
\hline Entrevistado 3 & 29 \\
\hline Entrevistado 4 & 33 \\
\hline Entrevistado 5 & 63 \\
\hline
\end{tabular}

\begin{tabular}{|l|r|}
\hline Entrevistados & Idade (anos) \\
\hline Entrevistado 6 & 52 \\
\hline Entrevistado 7 & 32 \\
\hline Entrevistado 8 & 23 \\
\hline Entrevistado 9 & 28 \\
\hline Entrevistado 10 & 33 \\
\hline
\end{tabular}

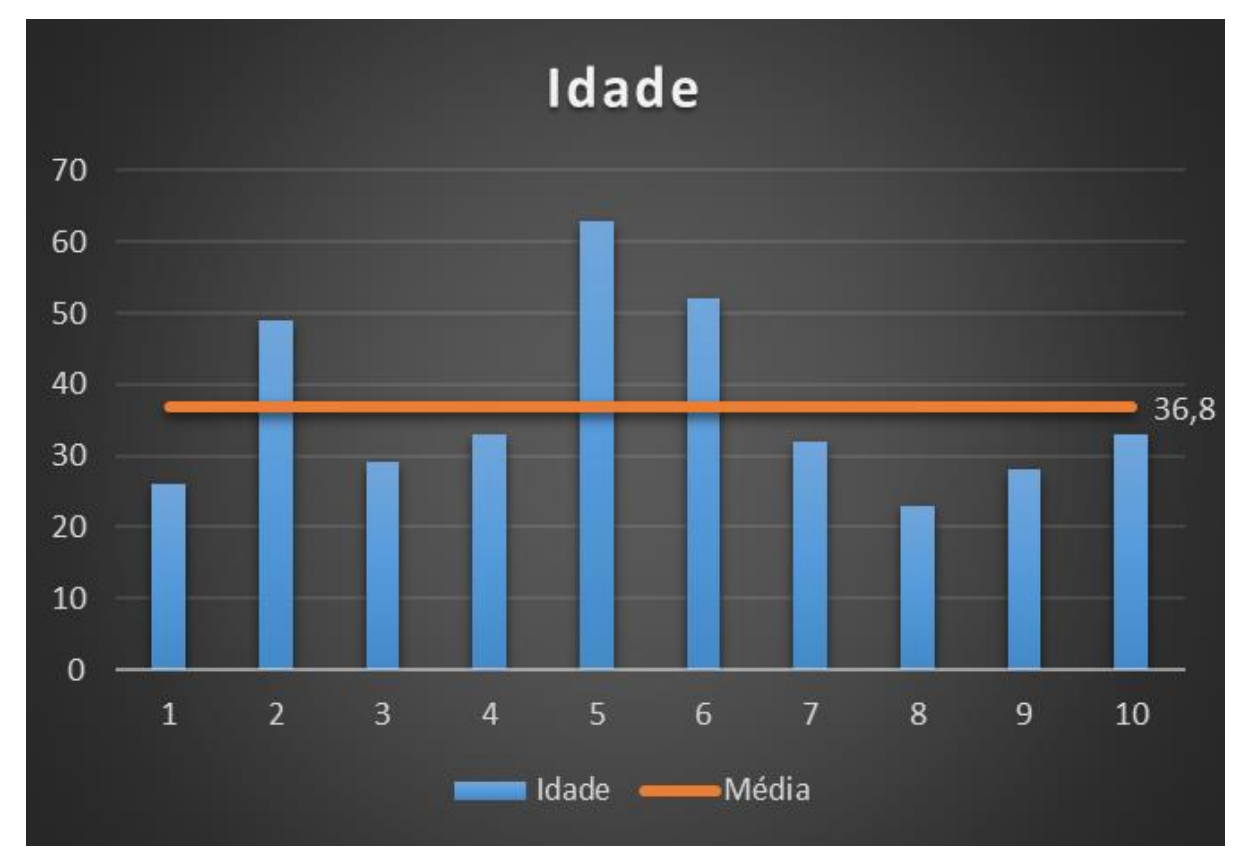

Figura 6: Perfil dos Entrevistados - Idade

Os entrevistados possuem diferentes formações acadêmicas, discriminadas a seguir. As diferentes graduações também poderão contribuir para análises mais profundas a respeito das profissões relacionadas à formulação do Planejamento Estratégico. A maioria dos executivos entrevistados é Administrador de Empresas, $50 \%$ dos entrevistados. 


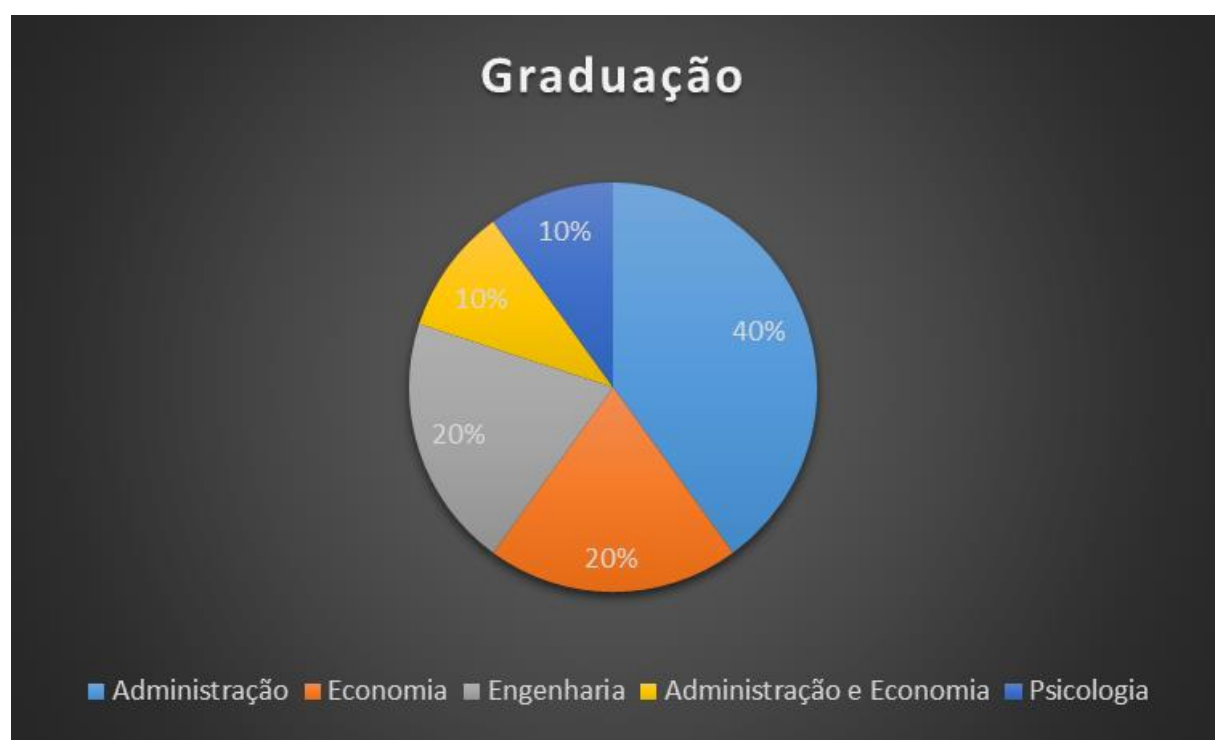

Figura 7: Perfil dos Entrevistados - Graduação

Houve um filtro para entender se os entrevistados tinham cargo de gestão ou não. Houve uma preocupação em não entrevistar apenas pessoas com cargos de gestão. É importante para a conclusão da pesquisa ter um olhar de baixo para cima. Neste ponto a principal questão é saber se o entrevistado possui uma equipe para gerir. A quantificação dos cargos de gestão foi detalhada a seguir. Apenas dois respondentes não possuem ou possuíam cargo de gestão em suas corporações.

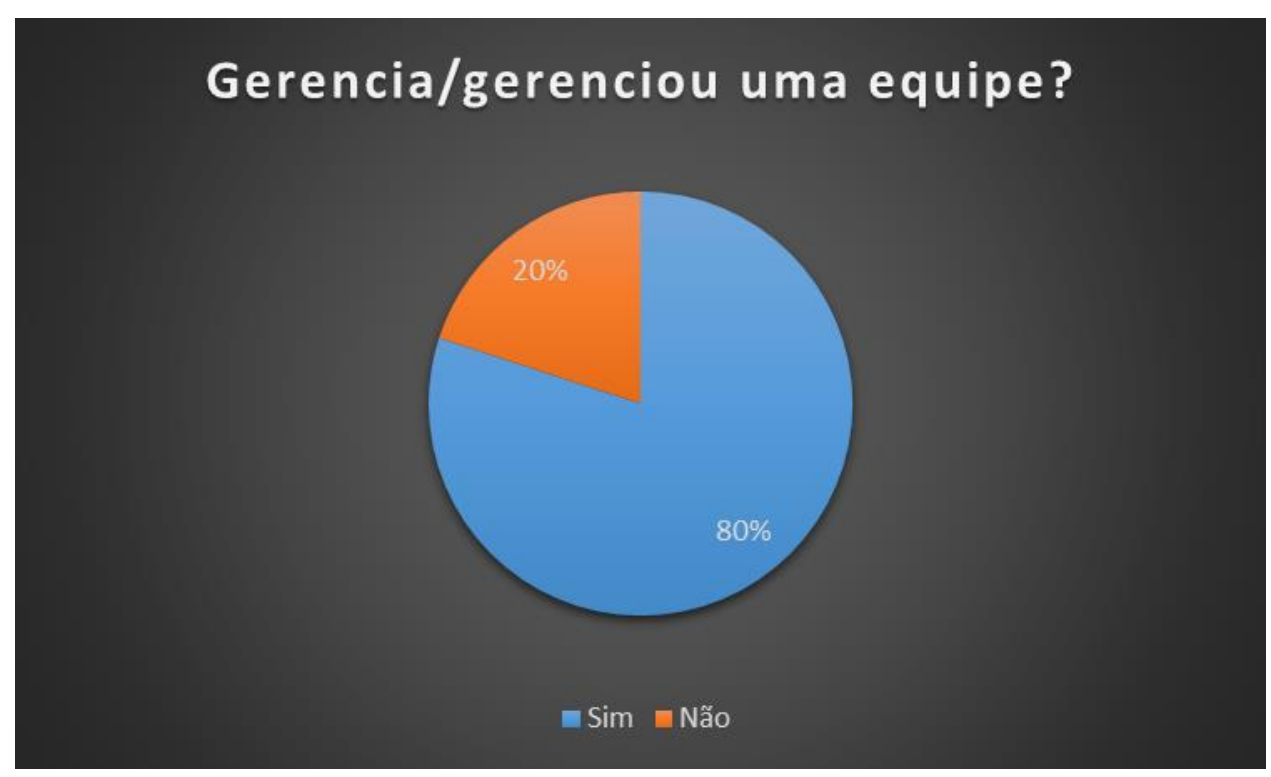

Figura 8: Perfil dos Entrevistados - Gerência de Equipes 
Como trata-se de uma pesquisa de Planejamento Estratégico, todos os entrevistados têm conhecimento sobre este tema. Porém, nem todos participaram da formulação da estratégia de suas empresas. A proporção dos que participaram e não participaram da elaboração está quantificada a seguir. Da mesma forma que os cargos de gestão, é importante ter uma opinião dos colaboradores que não participaram efetivamente da elaboração da estratégia. Dos 10 entrevistados, 6 tiveram participação efetiva na formulação, enquanto 4 participaram de outras formas.

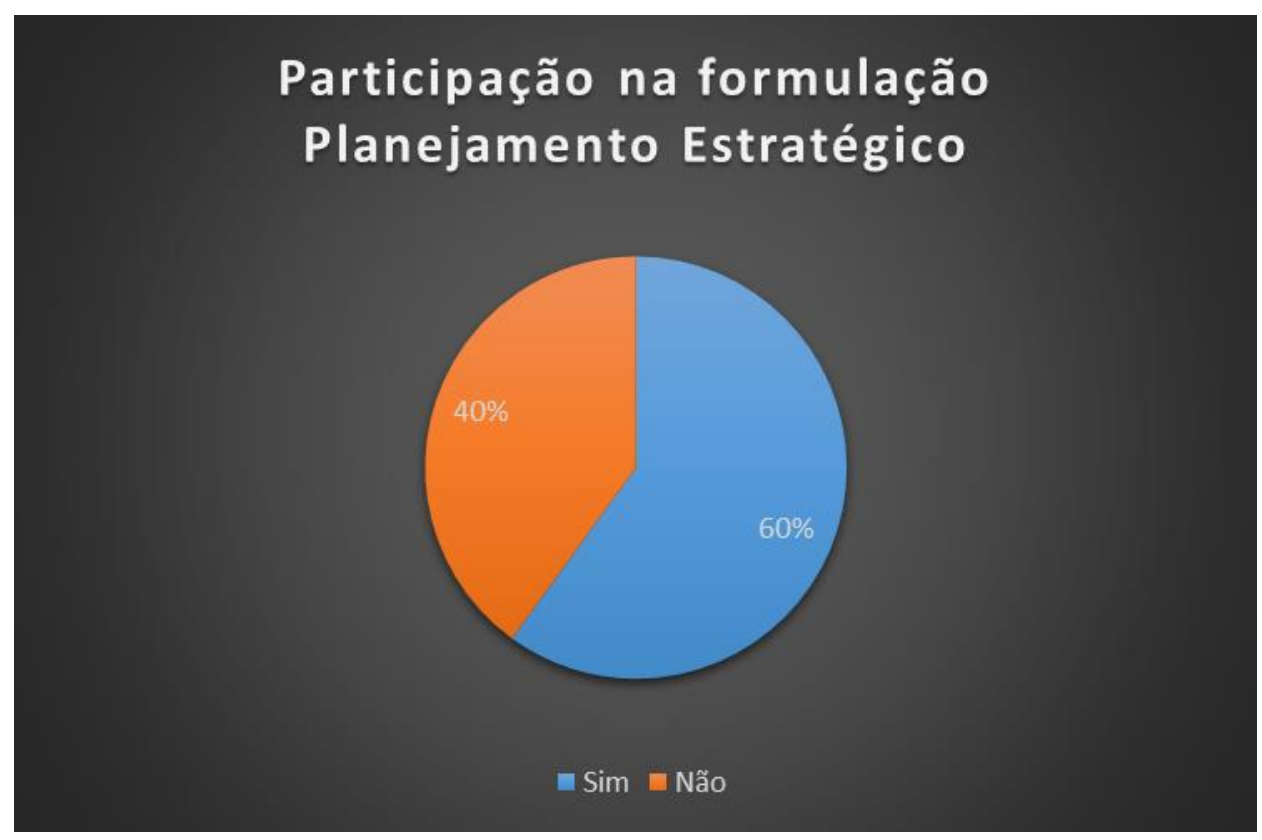

Figura 9: Perfil dos Entrevistados - Participação do Planejamento Estratégico

As áreas de atuação dos entrevistados foram bastante variadas, detalhadas a seguir. Apenas dois entrevistados são da mesma área técnica, Fusões e Aquisições. 


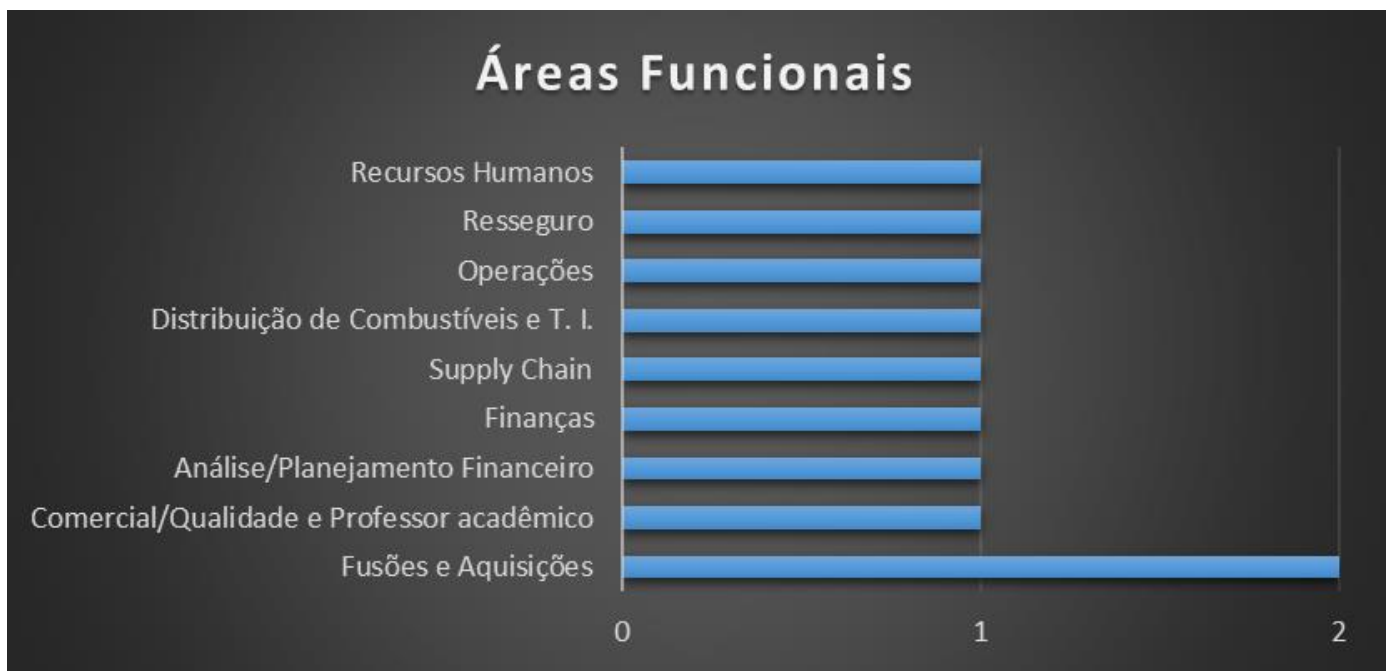

Figura 10: Perfil dos Entrevistados - Áreas Funcionais

Os cargos dos entrevistados são quantificados a seguir. É importante ressaltar que os cargos hierárquicos têm "pesos" diferentes dependendo da empresa. Por exemplo, um coordenador na empresa $X$ pode estar acima de um técnico e na empresa $\mathrm{Y}$ isso ser ao contrário. Isso foi levado em consideração na parte qualitativa da entrevista.

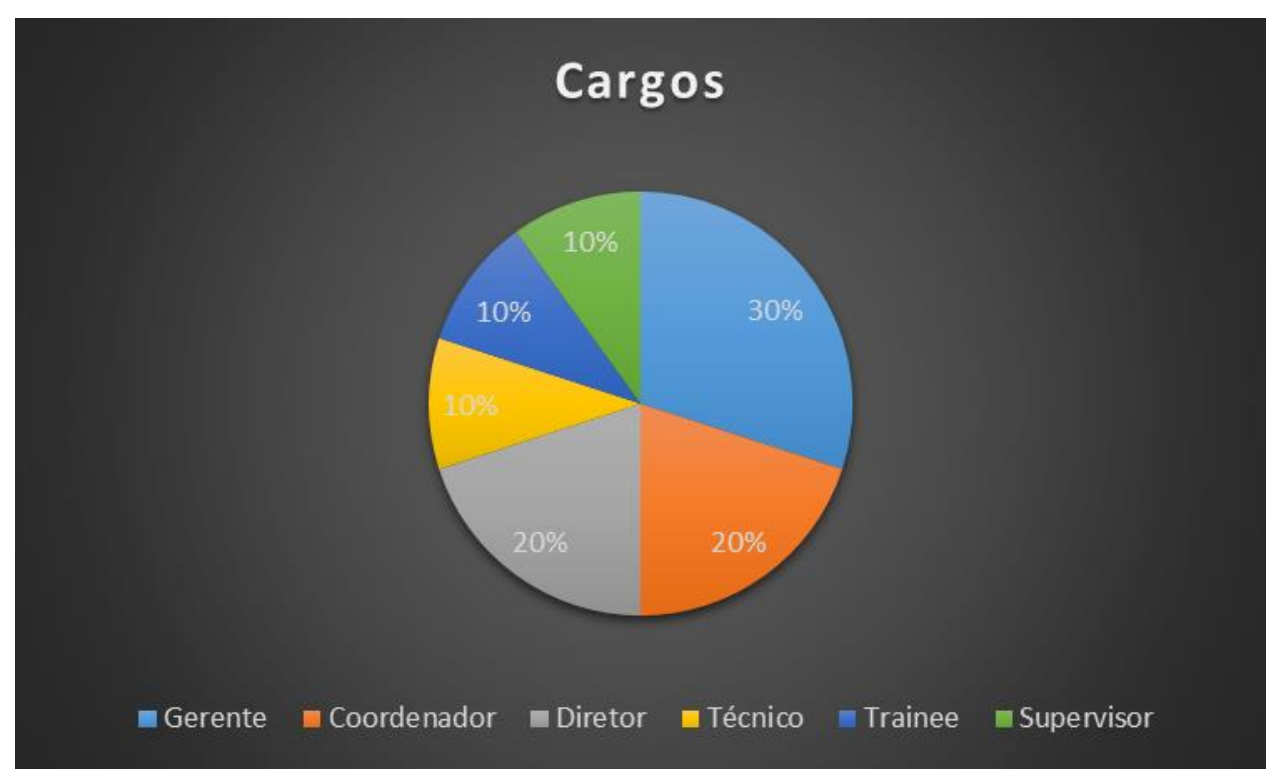

Figura 11: Perfil dos Entrevistados - Cargos 


\subsection{Análise dos resultados}

Neste subcapítulo serão analisados os dados qualitativos obtidos por meio a entrevista. A análise será dividida por pergunta realizada na entrevista nos subitens a seguir.

\subsubsection{Acompanhamento da Estratégia Formulada}

A pergunta para acompanhamento da estratégia formulada foi efetuada apenas para os entrevistados que participaram efetivamente da elaboração da estratégia. Dessa forma, foram oito respondentes. A pergunta padrão feita para cada executivo foi: Se sim (Já participou do Planejamento Estratégico de uma empresa?), houve acompanhamento da execução da estratégia formulada? Havia alguma ferramenta de controle da execução?

As respostas variaram entre táticas de controle simples como sistemas internos ou controles em Microsoft Excel e até reuniões semanais para acompanhamento de metas pré-estabelecidas. Esta última, demonstrou ser a mais eficiente na opinião do entrevistado. Após anos de carreira e tentativas mais rápidas e baratas, este decidiu gastar maior tempo para controle, através das reuniões de acompanhamento. Porém, foi possível perceber que o foco do controle estava mais para resultados, para as metas financeiras de cada colaborador. $\mathrm{Na}$ empresa deste executivo, as metas são desmembradas em metas individuais, metas gerais da companhia e meta de avaliação dos demais colaboradores, via avaliação $360^{\circ}$. Ao final da avaliação das três metas, o colaborador chega ao seu bônus, participação nos resultados da companhia, que receberá ao final do ano. Então, em conversa com o executivo, percebi que essa reunião tinha a maior parte do tempo para a avaliação do realizado pelos colaboradores do que pela estratégia formulada mais abrangente da companhia. Mas, mesmo assim, esta tática, mesmo que indiretamente, leva a uma análise do andamento da companhia e sua estratégia, podendo reverter as metas ao longo do ano corrente.

A resposta que mais chamou atenção dentre os entrevistados foi a exposta a seguir.

"Um planejamento estratégico só tem valor se for monitorado periodicamente, pois desta maneira podemos fazer ajustes no mesmo para alcançar as metas definidas. Trabalhei com várias ferramentas de Project 
Manager. O fundamental, independente da ferramenta de controle que será utilizada, é divulgar o plano para as equipes envolvidas e fazer acompanhamentos diários. "

O executivo tocou em dois pontos importantes na análise desta questão: monitoramento e comunicação interna. É imprescindível que haja comunicação da estratégia e que esta seja monitorada. Não há como controlar e cobrar algo que não é conhecido pelo outro. Se cada líder, seja líder qualquer colaborador com gestão de uma equipe, comunicar para sua equipe a estratégia que seu líder lhe passou e este for um processo comumente distribuído pela companhia, a estratégia é efetivamente semeada, e as chances de sucesso são elevadas. E, é necessário que a estratégia seja decomposta em níveis passíveis de análise, para assim poder monitorar e controlar o andamento desta.

Os demais entrevistados, seis executivos, $75 \%$ dos respondentes, disseram que havia controles superficiais ou não havia. $O$ destaque negativo foi para a Gerente de Recursos Humanos entrevistada, que declarou não conhecer qualquer ferramenta de controle da estratégia formulada. Este destaque negativo não se dá por ser apenas uma gerente, mas sim do departamento de Recursos Humanos.

Ou seja, para a maioria há pouco ou nenhum acompanhamento da estratégia planejada. E, as ferramentas de controle são em sua maioria muito simples e ineficazes. Então, o não acompanhamento da estratégia é um fator para o seu não cumprimento.

\subsubsection{Processo de Planejamento Estratégico}

A pergunta sobre este tema foi aplicada para todos os entrevistados, com o objetivo de entender como foi efetivamente o planejamento da estratégia corporativa, de acordo com a experiência dos executivos. A pergunta utilizada foi: Como ocorreu o Planejamento Estratégico (tendo participado ou não)?

Todos os dez entrevistados citaram reuniões da alta cúpula de suas empresas para a formulação da estratégia do ano seguinte. Dependendo do tamanho da empresa, os participantes das reuniões variam. Por exemplo, em empresas de capital aberto, há representantes dos maiores acionistas determinados pelo Conselho Administrativo. Em empresas familiares participam apenas os sócios. Em seguida, a maioria das corporações grandes convocam um grande evento para comunicação da estratégia formulada. Nele, são 
apresentados os maiores desafios e tudo o que foi traçado nas reuniões de Planejamento Estratégico. A partir desse ponto, a comunicação passa a influenciar o sucesso ou insucesso da estratégia formulada. Quando a nova estratégia é arrojada, este tem um peso ainda maior. É necessário que todos conheçam e estejam engajados para atingir os objetivos.

A resposta que mais chamou atenção dentre os entrevistados foi a exposta a seguir.

"O Planejamento Estratégico é feito com base em premissas utilizadas, portanto seu êxito estará totalmente condicionado a escolha de premissas certas/realistas. Vale também mencionar que os alvos devem ser sempre desafiadores, pois isto é que fará com que o time que executará tenha motivação para alcançar a meta. “

O entrevistado tocou em um ponto importante: previsibilidade. Sempre em que se fala de planejamento, há de haver um estudo do macro ambiente e traçar assim seus planos de ação através das premissas, conforme descrito no capítulo 2. Porém, esse estudo pode ser impreciso. Na verdade, na maioria das vezes ele é impreciso, pois prever o futuro não é tarefa simples. Há fatores, principalmente ligados ao ambiente externo que devem ser analisados com mais calma e critério. Por exemplo, podem haver problemas macroeconômicos ou presença de grandes fenômenos naturais que afetam a empresa integralmente. Portanto, é importante ter planos de contingência para caso o Plano " $A$ " tenha sido mal previsto. Nesse caso, havendo planos de ação diferentes para cada cenário, as chances de sucesso são efetivamente maiores.

\subsubsection{Colaboradores envolvidos no Planejamento Estratégico}

O objetivo deste ponto foi entender o percentual de participação do corpo de funcionários da empresa no planejamento da estratégia corporativa. Foi medido através da pergunta: Quantas pessoas foram envolvidas neste processo (percentual - aproximado - de pessoas da companhia)?

Em suma, todos os entrevistados relataram o percentual de participação de no máximo $5 \%$ da companhia. Os dois entrevistados que fizeram a conta aproximada chegaram em números como $0,6 \%$ e entre 1 e $2 \%$ da companhia. Os demais aproximaram demais a conta, relatando $5 \%$ da companhia. 
A resposta que mais chamou atenção está detalhada a seguir. "Vai depender muito do tipo de negócio, mas quando falamos de um planejamento estratégico entendo que $100 \%$ do time estará envolvido no processo. “

Nesta resposta, o entrevistado diz que depende do tipo do negócio. $\mathrm{Na}$ prática, isso significa que em determinados tipos de negócio a companhia envolverá maior ou menor parte de se corpo na elaboração da estratégia. Por exemplo, uma empresa familiar tende a envolver toda a família controladora do negócio na formulação das estratégias do ano seguinte. Em seguida, os resultados são comunicados para o resto da companhia. Além dessa distinção, o entrevistado mostrou a sua capacidade de envolver toda a companhia neste processo, algo que não é muito comum - apenas um dos dez respondentes tocaram neste ponto. O envolvimento da companhia com a estratégia é fator preponderante ao sucesso desta.

\subsubsection{Comunicação do Planejamento Estratégico}

Todos os entrevistados responderam este ponto através da pergunta a seguir: Como o Planejamento Estratégico foi comunicado aos demais colaboradores da companhia?

O objetivo é entender o desmembramento da estratégia para os níveis abaixo. O método de comunicação mais citado foi a intranet da companhia. Este é um método barato, porém nem sempre eficaz pois em muitas empresas elas praticamente não são acessadas. Mas, quando há a cultura de uso frequente da intranet pelos colaboradores, o efeito é satisfatório. Foram citados também emails generalizados para toda a companhia. Mas, método citado por um dos dez entrevistados foi o melhor dentre todos. Este citou que independentemente do planejamento ele, no papel de líder, comunicava sua equipe os detalhes. Enquanto isso, a empresa comunicava via jornal e intranet, campanhas de comunicação. Então, se a ação deste executivo for disseminada por outros gestores da companhia, a chance de todas as pontas terem a informação correta em mente é maior, seja pelo gestor ou pela divulgação interna da companhia. Assim, eleva-se a chance de sucesso no atingimento das metas.

Para melhor avaliar este tema, foi feita uma pergunta específica aos entrevistados que não tiveram experiência na elaboração de um Planejamento Estratégico. "Caso não tenha participado do Planejamento Estratégico, como as informações chegaram a você?" 
Dessa forma, houve quatro respondentes. As formas citadas se assemelham à pergunta anterior: reuniões com o gestor direto, intranet, e-mails e murais na companhia. Chamou-me atenção que um dos respondentes disse que não recebeu nenhuma informação a respeito da estratégia, com exceção de informações como missão, visão e valores. Como o entrevistado é um profissional júnior, a informação não chegou a ele por um dos três motivos: gestor imediato não soube comunicar as informações que recebeu (entende-se que isto é um ciclo virtuoso em uma companhia - se desde os criadores da estratégia, topo da pirâmide, todos passarem a informação em direção à base, a companhia estará informada como um todo); houve uma falta de interesse do entrevistado pelo assunto; há falhas de execução da estratégia graves na companhia. É necessário, também, que haja interesse dos colaboradores de entenderem e participarem do processo.

\subsubsection{Eficiência na execução do Planejamento Estratégico}

Este tema foi exposto aos entrevistados de forma direto através da pergunta a seguir: Qual a sua opinião sobre a eficiência da execução do Planejamento Estratégico nas empresas em que você passou?

Essa pergunta foi remetida a todos os dez entrevistados e procurou medir de forma geral a execução da estratégia corporativa nas empresas em que os entrevistados passaram. Com exceção de dois entrevistados houve um consenso de que a execução da estratégia planejada não é eficiente. Os dois entrevistados são colaboradores de uma mesma empresa com reputação de execução certeira, e ambos relataram que suas empresas anteriores eram diferentes. Ou seja, planeja-se algo e este não é efetivamente colocado em prática. Mais uma vez tocou-se no tema comunicação, fator chave para a disseminação do planejado e consequente atingimento das metas. Um dos entrevistados citou que as metas financeiras sempre são alcançadas, e na sua opinião isso ocorre devido à participação nos lucros dos colaboradores. De outro lado, o respondente acredita que faltou seguir o que foi planejado. Apesar de ser normal rever o planejado ao final do ano, o realizado deve ter alguma conexão com o planejado.

Outro entrevistado contou uma experiência importante de reestruturação da empresa na qual era Gerente e implementação de uma nova cultura. Sua empresa havia sido adquirida pelo Banco Garantia, que na época era o grande 
exemplo de cultura forte. O resultado explicitado pelo entrevistado foi que houve muita resistência por parte dos antigos colaboradores. Essa resistência, na sua opinião é algo cultural que só seria resolvido com a demissão dos antigos colaboradores e uma readequação de pessoal com base na estratégia proposta. Nesse ponto, o entrevistado citou um conceito importante para entendermos o assunto execução do Planejamento Estratégico: é necessário haver um clima de liberdade intelectual. Não há como todos pensarem da mesma forma, todos devem ter espaço para agir e se expor. Havendo isso, a companhia chegará a um senso comum e os resultados logo aparecerão. Na prática, isso quer dizer que não adianta haver o presidente da companhia com a estratégia "no sangue" porque esta não obterá sucesso em condições normais. A disseminação é processo chave no alcance dos resultados, todos devem estar engajados neste processo.

\subsubsection{Execução da missão corporativa}

Para avaliar este tema foi questionado aos dez entrevistados a pergunta a seguir, antecedida por uma breve introdução: Dentre os componentes de uma estratégia corporativa há a definição de missão e valores. Qual sua opinião sobre a execução da missão das empresas em que você trabalhou/trabalha?

Foi praticamente um consenso que a missão da companhia é importante e que para haver sucesso deve haver foco na execução. Um único executivo entrevistado, Economista, citou que a criação de missão corporativa, na sua opinião, é um assunto pouco relevante. Esta simples e direta resposta nos faz refletir sobre o assunto e buscar uma resposta para esse tema. Não é possível generalizar ao ponto de dizer que todo economista pensa dessa forma, mas é possível em um estudo futuro desvendar essa dúvida. Isso ocorre pois não deve ser avaliado apenas a profissão do respondente. Existem outros fatores que podem influenciar na opinião das pessoas, como empresa na qual trabalhou/trabalha, setor empresarial, cargo além da própria profissão. Mas, voltando ao tema missão, a grande maioria retratou a importância da eficiência da escolha da missão, pois ela moverá toda a companhia. Não foram retratados casos práticos de falhas na execução da missão, mas todos disseram acreditar que a execução pode melhorar. Os dois entrevistados em que suas empresas têm cultura extremamente fortes, ressaltaram que sua empresa atual exerce rotineiramente todos os componentes de sua estratégia, mas que nas empresas 
anteriores a situação era diferente. Mais uma vez, a comunicação é assunto chave, destacando o papel de cada líder na disseminação da missão. A declaração a seguir é de um dos executivos entrevistados, que reflete sobre os assuntos comentados acima.

"Sempre busquei alinhar meu trabalho à missão das companhias em que passei. Esse processo deve ser top-bottom, com os líderes dos grupos repassando e contagiando suas equipes. Assim, o processo está totalmente vinculado a capacidade dos líderes de assimilarem a missão. "

A visão da profissional de Recursos Humanos é importante nesse ponto. Esta área é responsável por recrutar e desenvolver os colaboradores. Então, é primordial que a área esteja alinhada com a estratégia da companhia. A seguir é apresentada a resposta da Gerente de $\mathrm{RH}$ entrevistada. Ela vê lacunas na companhia como um todo, mas coloca a cultura empresarial como prioridade nas suas rotinas.

"A execução é vista em alguns momentos na prática, mas sinto falta de um maior reforço em relação a isso, inclusive de colaboradores em posições mais seniores. De qualquer forma, enquanto Recursos Humanos busco reforçar de certa forma aos candidatos e aos colaboradores internos o que devemos seguir para montar qualquer projeto e/ou estratégia."

Um dos entrevistados citou um exemplo prático de uma empresa em que trabalhava. Sua missão era algo semelhante a "reconhece a melhor oferta do mercado com base em vantagens e benefícios claros", porém o respondente disse que nem sempre isto era verdade.

Então, com base nas respostas das entrevistas, a missão corporativa é importante, mas não é executada nem conhecida por todos os colaboradores da companhia.

\subsubsection{Execução dos valores da companhia}

Dando seguimento a execução da missão, foram questionadas aos dez entrevistados suas opiniões sobre a execução dos valores através da pergunta a seguir: Qual sua opinião sobre a execução dos valores da companhia em que você trabalhou/trabalha?

A proposta é similar a pergunta anterior, e teve como objetivo entender como a companhia lida com os valores estabelecidos. Os valores orientam o negócio e principalmente a maneira de fazê-los. Então, os colaboradores têm 
que tê-los em mente para orientar o negócio da melhor forma possível. Quando se está lidando com uma empresa com cultura forte, os colaboradores que não têm os valores impregnados no seu intelecto tendem a não se adaptar à companhia, não permanecendo por muito tempo neste.

Mais uma vez a figura do líder é importante para a propagação dos valores. Um dos executivos disse que a maior parte do mercado não utiliza os valores no seu dia a dia, mas que ele propaga os valores através de suas ações e tomadas de decisão do dia a dia baseados neles. Outra opinião marcante foi que a definição de valores é uma "obrigação", mas a prática quase sempre foi diferente da realidade. Essa "obrigação" se dá, pois, as empresas grandes possuem missão, visão e valores declarados para o mercado. Ao entrar no site de qualquer grande empresa, facilmente serão encontrados esses itens lá expostos. Uma empresa sem valores não perpetua no mercado. Ter esses pontos expostos garantem a imagem da companhia, que deve ser alinhada com a prática. É muito comum a definição de alguns valores "da moda". No momento, as empresas adotaram Sustentabilidade como valor essencial para se ter em usa carteira. Pessoas é outro valor muito comum. Porém, é amplamente necessário que para que a empresa adote pessoas como valor, esta valorize as pessoas conforme relata. Um dos entrevistados relatou sua experiência em um processo seletivo em que este chegou antecipadamente ao horário marcado. Ao passar aproximadamente uma hora ao horário marcado os responsáveis pela entrevista não haviam aparecido. Um dos valores da empresa era Pessoas ou Gente (o entrevistado não soube precisar, mas o significado dos dois é o mesmo). Ao passar dos minutos, o entrevistado se questionava sobre o valor da companhia: uma empresa que age dessa forma com um candidato não pode ter Pessoas como valor corporativo. Eis um exemplo clássico de falha na execução de um dos valores.

\subsubsection{A relação dos valores corporativos com os processos de recrutamento e seleção}

Prosseguindo com a análise da execução dos valores corporativos, foi elaborada uma questão aos dez entrevistados, referindo-se especificamente aos processos de recrutamento e seleção da companhia. A pergunta foi dirigida da seguinte forma: Em teoria, os colaboradores de gestão de pessoas $(\mathrm{RH})$ devem estar alinhados aos valores da companhia para assim recrutar recursos que 
tenham os mesmos valores. Isso é/era uma realidade das companhias em que você passou?

Dos dez respondentes, seis negaram a resposta. Dos quatro que disseram que sim um é profissional de recursos humanos, fato que chama atenção frente a maioria negativa. Outros dois fazem parte de uma companhia com cultura extremamente forte, onde há efetivamente execução dos valores e os colaboradores que não os seguirem são rapidamente eliminados da companhia. Pelo resultado da pesquisa essa empresa é uma exceção. As empresas, então, deixam a desejar no cumprimento desse "dever".

O grande fator que move essa pergunta é que a área de Recursos Humanos deve estar totalmente alinhada com a cultura da companhia. Caso contrário recrutarão errado e o contratado não conseguirá se encaixar na companhia, com exceções. É mais fácil contratar alguém que tenha os valores da companhia em mente do que ter que "reeducar" a pessoa à companhia. Assim, desperdiça-se tempo e dinheiro. No caso de empresas que passam por reestruturação de valores, é comum haver demissões em massa. Porém, neste caso, "reeducar" é o melhor caminho.

Independentemente do perfil do contratado, assim que o novo colaborador for admitido, é essencial "mergulhá-lo" na cultura da companhia. Muitas vezes o novo contratado conhece boa parte da empresa nos longos processos seletivos, mas isso não anula a introdução deste no meio. A história da empresa deve ser valorizada, seguido das estratégias, incluindo missão, visão e valores. Assim, o novo funcionário será parte integrante da empresa, padronizando a forma de pensar e agir na companhia. É importante ressaltar que essa ambientação tem um custo financeiro envolvido, porém é recuperado rapidamente. Os novos recrutados que não se encaixarem com a companhia logo serão retirados, dando prosseguimento ao processo. Também é importante ressaltar que não são todas as empresas que possuem estrutura para isso. Essa estrutura é tanto física, como salas e pessoal especializado em treinamento, quanto ao próprio material (história; missão, visão e valores declarados; organograma; treinamentos entre outros). Essas devem ter maior criticidade no recrutamento ou então pensar em investir em uma estrutura de ambientação. Em uma das empresas dos entrevistados, há um andar da sede de sua companhia totalmente exclusivo para treinamentos tanto de introdução como de desenvolvimento interno. Isso acelera o crescimento dos colaboradores internos e consequentemente o crescimento da companhia semeado por sua estratégia. 


\section{Conclusões e recomendações para novos estudos}

\subsection{Conclusões sobre a resposta do problema}

A grande questão desta pesquisa é entender se a execução da estratégia corporativa é realmente alinhada com o seu planejamento, e o que ocorre nos casos em que a execução não foi eficiente. Além disso, são propostos fatores importantes que facilitam a execução da estratégia formulada.

O embasamento da solução desse problema é um confronto entre os dados coletados das entrevistas no capítulo 4 e o referencial teórico do capítulo 2. Como foi apresentado no capítulo 2, há estudiosos com opiniões opostas como Kaplan e Norton (2000) e Mintzberg (2000). Parte dos autores acha que há lacunas entre planejamento e execução e outra parte entende que isto não é uma realidade. De forma menos igualitária, o capítulo 4 permitiu a tomada de algumas conclusões a respeito do tema. A execução da estratégia corporativa é um problema cotidiano de algumas empresas. Porém, há empresas na qual sua cultura corporativa é extremamente forte, tornando natural a execução da estratégia planejada, mesmo que esta seja modificada com o decorrer dos períodos. Portanto, a estratégia corporativa não é alinhada com seu planejamento em algumas companhias. Isto ocorre pela falta de alguns pontos, retratados a seguir.

Após realizar a pesquisa, foi possível traçar métodos que, se utilizados, aumentam as chances de sucesso na execução de sua estratégia. Os entrevistados com maior experiência com gestão e vida corporativa trouxeram experiências, positivas e negativas, que os levaram a definir alguns métodos e baseei-me neles. Serão, então, apresentados pontos que visam ser soluções para as estratégias não executadas na prática. Este é o maior legado deste trabalho.

O primeiro ponto é a comunicação interna. Toda a companhia deve estar engajada no processo de gestão estratégica. Para isso, todos devem receber a mesma informação simultaneamente. Existem diversas formas de comunicação do Planejamento Estratégico. Dentre elas, destaca-se, inicialmente, o evento de formalização do Planejamento Estratégico. Não são todos que participam, normalmente envolvendo parte da alta cúpula da empresa. Ali todos os gestores 
participantes têm a ciência do que foi planejado. A partir disso, inicia-se a comunicação de baixo para cima da empresa dos gestores para suas equipes. Esta é a principal forma de propagação eficiente do Planejamento Estratégico, onde os planos são apresentados e as dúvidas são tiradas. Em comum sintonia aos líderes individuais, a corporação deve comunicar as decisões via murais na companhia, intranet, e-mails e qualquer outro tipo de forma de comunicação in company. Assim, a companhia "caminha" para uma mesma direção, alocando os recursos no local correto, conforme imagem exposta no capítulo 2.3.

O segundo ponto é traçar formas de controle do andamento da execução da estratégia. A estratégia é desmembrada em metas mensuráveis e passíveis de avaliação de seu andamento. E, assim são controladas através de sistemas de informação. Há controles mais baratos como planilhas no Microsoft Excel e mais caros como sistemas informatizados baseados na metodologia Balanced Scorecard. Ambos garantem, com diferentes níveis de eficiência, que a estratégia está em andamento, com o atingimento das metas estabelecidas.

O terceiro ponto é ligado à interface entre à formulação e execução. Quando as estratégias são formuladas, determinadas premissas são assumidas. Essas podem ou não ter desvios da realidade, sejam relacionadas ao ambiente interno ou externo. Para amenizar seus impactos, há a definição de planos alternativos, de contingência. Se determinada premissa tiver uma realidade diferente da assumida, muda-se o foco da estratégia para o plano alternativo. Então, é extremamente importante controlar o andamento das premissas, de forma a antecipar determinados acontecimentos no ambiente, Assim, há tempo para executar a mudança, garantindo que o plano de contingência seja cumprido. A assertividade da escolha das premissas, definindo diferentes cenários, é primordial para que a estratégia seja efetivamente executada.

O quarto, e último, ponto envolve a cultura da companhia. É comum que não haja consenso entre todos os colaboradores de todos os planos formulados. Muitas vezes, representantes de diferentes áreas buscam caminhos inversos, vide exemplo de uma área comercial e de logística. A área comercial planeja vender a maior quantidade possível, enquanto a área de logística planeja executar as cadeias de distribuição da forma mais eficiente. As divergências podem surgir quando o comercial quer aumentar o volume de vendas, mas a logística não comporta entregar o aumento de quantidade, preferindo manter o volume de vendas e melhorar a eficiência logística. Explicado o exemplo, o último ponto citado é o clima de liberdade intelectual. Ou seja, há divergências de pensamentos, mas todos conseguem viver em harmonia, expondo seus 
pontos de vista e chegando a melhor conclusão possível. Dessa forma, os recursos são melhor alocados e minimizados e o clima organizacional é melhor, gerando um ciclo virtuoso.

Um dos componentes do Planejamento Estratégico é a formulação da missão, visão e valores corporativos. Estes pilares são ignorados em algumas companhias no seu cotidiano. Porém, os valores corporativos são importantíssimos, pois definem as regras que guiam os colaboradores a forma de se comportar e agir. Seguindo os valores e executando a missão, a visão será alcançada. Além disso, os valores formam a imagem da companhia enquanto negócio. Então, deve haver maior enfoque das companhias para controlar e garantir que estes estão sendo cumpridos pelas diversas áreas e representantes da companhia.

Em tempos de austeridade, toda a companhia deve estar alinhada para que haja eficiência na execução de seus processos-chave. Então, garantindo uma eficiência na execução do planejado, há como garantir que recursos não serão planejados, pois o planejamento foi, ou deveria ter sido, realizado com base no cenário que economizasse recursos.

\subsection{Conclusões sobre às hipóteses}

Antes de realizar a pesquisa com os executivos, havia uma hipótese formulada, com base nas experiências nos estágios corporativos dos alunos de graduação em Administração de Empresas. Esta hipótese, descrita no capítulo 1, citava que havia um descasamento entre a estratégia planejada e a executada, baseada nas três primeiras experiências.

Esta suposição foi confirmada nos capítulos 4 e 5.

\subsection{Recomendações para novos estudos}

Após a análise dos dados coletados pelas entrevistas deste trabalho, alguns pontos não foram possíveis de serem alcançados. Não foi possível fazer uma relação entre a relevância da execução do Planejamento Estratégico com um determinado perfil de executivo (idade, gênero, profissão, entre outros).

Um dos problemas encontrados que leva a um erro de execução da estratégia foi a má escolha das premissas. Esse seria um erro no Planejamento 
Estratégico em si, um erro de entendimento do macro ambiente. Portanto, em um estudo futuro será possível entender lacunas na própria formulação do Planejamento Estratégico. Este estudo focou em lacunas na execução, apenas.

Seria relevante, também, entender que tipos de companhia executam ou não sua estratégia conforme formulada no Planejamento Estratégico.

Outra recomendação para futuros estudos é identificar o porquê de as empresas que não executam corretamente sua estratégia investirem em Planejamento Estratégico sem dar o enfoque necessário à sua execução, desperdiçando recursos tão importantes, sejam recursos humanos ou financeiros. Seria o caso de "obrigações" para com seus acionistas?

Focando em subitens da estratégia corporativa, seria relevante realizar estudos de casos focados em diferentes tipos de corporações entendendo a missão, visão e colaboradores. Esses estudos poderiam questionar o conhecimento e a utilização dos colaboradores sobre esses três pontos, individualmente. 


\section{Referências Bibliográficas}

ANDREWS, Kenneth. R. The Concept of Corporate Strategy. Homewood, IL: Richard D. Irwin, 1971.

BASSO, C. As dez escolas da Administração Estratégicas. Portal Administradores, 04 set. 2011. Disponível em: < http://www.administradores.com.br/artigos/cotidiano/as-dez-escolas-daadministracao-estrategica/58015/>. Acesso em: 15 de setembro de 2015.

CERTO, S. C.; PETER, J. P. Administração estratégica: planejamento e implantação da estratégia. São Paulo: Makron Books, 1993.

CHIAVENATO, I. Planejamento Estratégico. São Paulo: Elsevier, 2004.

COLLINS, J. Como as Gigantes Caem. Rio de Janeiro: Elsevier, 2010.

CORDEIRO, José Vicente Bandeira de Mello. Alinhamento estratégico: estudos multicasos em empresas paranaenses de médio porte. 2005. 299 p. Tese (Doutorado em Engenharia de Produção) - Programa de Pós-Graduação em Engenharia de Produção, UFSC, Florianópolis.

CORRÊA, K. Alinhamento Estratégico. Portal Administração e Gestão, 22 ago. 2008. Disponível em: <http://www.administracaoegestao.com.br/planejamentoestrategico/alinhamento-estrategico/>. Acesso em: 16 de setembro de 2015

CORREA, V. Por que existem tantos frustrados no curso de Administração? Portal Administradores, 23 jan. 2013. Disponível em: <http://www.administradores.com.br/mobile/artigos/carreira/por-que-existemtantos-frustrados-no-curso-de-administracao/68432/> Acesso em: 23 de abril de 2016

KAPLAN, R. S.; NORTON, D. P. Organização orientada para a estratégia: como as empresas que adotaram o Balanced Scorecard prosperam. Rio de Janeiro: Campus, 2000.

KAPLAN, R. S.; NORTON, D. P. The Balanced scorecard: translating strategy into action. Boston: Harvard Business School Press, 1996.

MAXIMIANO, A. Introdução à Administração. 6. ed. São Paulo: Atlas, 2006.

MIETTO, D.; JESUS, A. Como promover o alinhamento estratégico nas empresas. Sem ano: Multitalento

MINTZBERT, H. Safári de Estratégia. Porto Alegre: Bookman, 2000.

PETTIGREW, A. M.; WHIPP, R. Managing change for competitive success. Oxford: Basil Blackwell, 1993. 
QUINN, J. B. Strategies for change: logical Incrementalism. Homewood, Illinois: Irwin, 1980.

ROCHA, F. Avaliação do alinhamento estratégico em uma pequena empresa do segmento agroindustrial do RN. Bento Gonçalves: XXXII Encontro Nacional de Engenharia de Produção, 2012.

SCHUMPETER, J. A. Capitalism, socialism and democracy. New York: Harper \& Row, 1950.

SUN TZU. A arte da guerra. Rio de Janeiro: Record, 2000.

TACHIZAWA, T. Organização Flexível: qualidade na gestão por processos. São Paulo: Atlas, 2006.

WHEELWRIGHT, S. C. Manufacturing strategy: defining the missing link. Strategic. Management Journal, v. 5, p.77-91, 1984. 


\section{ANEXO I}

\section{Por que existem tantos frustrados no curso de Administração?}

É comum encontrar graduandos desiludidos com o curso

Por: Vitor Correa

23 de janeiro de 2013

Ao longo dos meus quatro anos na graduação em Administração não foram poucas vezes que me deparei com lamúrias de colegas em relação ao curso. Existiam vários tipos de frustrados. Alguns gostariam de estar em cursos como música e artes plásticas, mas o medo e a incerteza sobre o seu futuro profissional não os levavam para lá. Outros gostariam de estar em alguma das engenharias, mas a dificuldade do vestibular, o preço de uma faculdade particular ou o medo por cálculos também não deixavam essas pessoas irem para lá. Existiam também aqueles que realmente não faziam ideia da sua vocação, logo, escolheram Administração.

O conhecido bordão: "Não sabe o que quer? Então faz Administração porque é amplo", é muito utilizado, não há como negar. Mas será que ele realmente contribui para os indecisos?

Segundo o "guia do estudante" da Editora Abril, "Administração é o gerenciamento dos recursos humanos, materiais e financeiros de uma organização. O administrador é o profissional responsável pelo planejamento das estratégias e pelo gerenciamento do dia a dia de uma empresa". Note que as palavras organização e empresa são o foco da profissão, ou seja, estudar Administração é estudar negócios, estudar empresas, as chamadas pessoas jurídicas.

Por que ninguém diz: "faça medicina, é muito amplo. Você pode atuar como cardiologista ou como oftalmologista, dentre outras áreas"?

Muitos iriam dizer: "mas para ser médico é preciso ter dom, ou melhor, vocação". E Administração? Será que não é preciso ter dom? Se cuidar e estudar uma pessoa física e suas particularidades é preciso ter dom, por que para estudar pessoas jurídicas e suas particularidades também não se precisa de dom? 
Pessoas jurídicas podem ser mais complicadas do que pessoas físicas, até porque são a união de várias pessoas físicas interagindo sob processos, normas, hierarquias etc. O administrador está para os negócios da mesma forma que o médico está para o ser humano.

$\mathrm{E}$ da mesma forma que não é qualquer um que tem desejo, gosto e paciência para estudar o Complexo de Golgi e os aminoácidos, não é qualquer um que tem os mesmos atributos para estudar contabilidade e lote econômico de compras.

Para estudar Administração é preciso gostar de empresas, gostar de negócios ou no mínimo de alguma particularidade referente ao estudo de organizações. Se a sociedade não mudar, ou melhor, consertar a sua visão sobre o que realmente é o curso de Administração, vamos continuar com alunos frustrados no curso, que se formam apenas para conseguirem um curso superior. Esse tipo de estudante normalmente tem grande dificuldade para se tornar um profissional qualificado, e isso, certamente, é ruim para o curso e para a visibilidade dos profissionais perante a sociedade!

Vale à pena refletir a respeito! 


\section{ANEXO 2}

\section{Roteiro de entrevista Planejamento Estratégico}

Idade:

Sexo:

Setor empresarial e/ou empresa:

Área:

Cargo:

Graduação em:

1. Gerencia/gerenciou uma equipe?

1. Já participou do Planejamento Estratégico de uma empresa?

2. Se sim, houve acompanhamento da execução da estratégia formulada? Havia alguma ferramenta de controle da execução?

3. Como ocorreu o Planejamento Estratégico (tendo participado ou não)?

4. Quantas pessoas foram envolvidas neste processo (percentual aproximado - de pessoas da companhia)?

5. Como o Planejamento Estratégico foi comunicado aos demais colaboradores da companhia?

6. Caso não tenha participado do Planejamento Estratégico, como as informações chegaram a você?

7. Qual a sua opinião sobre a eficiência da execução do Planejamento Estratégico nas empresas em que você passou?

8. Dentre os componentes de uma estratégia corporativa há a definição de missão e valores. Qual sua opinião sobre a execução da missão das empresas em que você trabalhou/trabalha? 
9. Qual sua opinião sobre a execução dos valores da companhia em que você trabalhou/trabalha?

10. Em teoria, os colaboradores de gestão de pessoas $(\mathrm{RH})$ devem estar alinhados aos valores da companhia para assim recrutar recursos que tenham os mesmos valores. Isso é/era uma realidade das companhias em que você passou?

11. Você já presenciou algum caso de falha na execução de algum item da estratégia corporativa? 